\title{
Risk Shifting, Debt Governance and Managerial Incentives*
}

\author{
Toke Hjortsh $\varnothing \mathrm{j}^{\dagger}$ and Chenyang $\mathrm{Wei}^{\ddagger \S}$ \\ Preliminary version, comments are welcome
}

March 29, 2007

\begin{abstract}
This paper studies the impact of debt governance on firms' risk shifting behavior. We construct firm-level debt governance indices using corporate bond indenture provisions, and a market-based risk shifting measure estimated using a contingent-claim framework. We first document that firms with strong debt governance subsequently lower business risk relative to their industry peers, and this relationship mainly exists among firms with high default probability. Further evidence suggests that debt governance plays an important role in mitigating the impact of managerial risk-taking incentives on risk shifting. Higher sensitivity of CEO wealth to stock volatility (Vega) is significantly positively related to risk shifting, but this effect is significantly weakened when strong debt governance is in place. Also, bondholders appear to benefit from the impact of debt governance on risk shifting. Higher Vega is associated with higher credit spreads for bonds under weak debt governance. Under strong debt governance, higher Vega is associated with significantly lower credit spreads.
\end{abstract}

JEL classification: G13, G30, G32, J33

Keywords: Risk shifting, default risk, debt governance, managerial incentive

\footnotetext{
*The authors are grateful for helpful comments from Kose John and Peter Tind Larsen. We would also like to thank seminar participants at University of Aarhus. Any remaining errors are the authors' responsibility.

†School of Economics and Management, University of Aarhus, Denmark. Tel.: +45 89422137 . E-mail: thjortshoej@econ.au.dk.

${ }_{\ddagger}$ Capital Markets Research Function, Federal Reserve Bank of New York. Tel.: 212-720-5995. Email:Chenyang.Wei@ny.frb.org.

$\S$ The views expressed represent those of the authors only and not necessarily those of the Federal Reserve Bank of New York or the Federal Reserve System.
} 


\section{Introduction}

The economics of risk shifting (or asset substitution) has long been established in the finance literature. ${ }^{1}$ With limited liability, equityholders of a levered firm have incentives to increase the firm's risk once the debt is in place. Debtholders use covenants as the governance mechanism to protect their investments from various types of shareholder-debtholder agency conflicts. For example, Smith \& Warner (1979) discuss covenants as addressing four categories of conflicts dividend payment, claim dilution, asset substitution and underinvestment. ${ }^{2}$ This study investigates the impact of debt governance on the firm's risk taking behavior. We ask three questions: What is the relationship between debt governance and the firm's risk-shifting behavior? What is the role of debt governance in mitigating the impact of managerial risk-taking incentives on the firm risk? What implication does our study have for the design of corporate governance?

The literature has been inconclusive about the importance of the risk shifting problem. For example, although Black \& Scholes (1973) and Jensen \& Meckling (1976) theoretically illustrate the potential conflicts between equityholders and debtholders, Leland (1998) derives a contingentclaim framework to find that the importance of the risk shifting problem is small. Although the relevance of risk shifting behavior in the financial industry is well recognized both theoretically and empirically, ${ }^{3}$ Parrino \& Weisbach (1999) conduct a numerical study and conclude that the empirical evidence of risk shifting behavior among industrial firms is limited. Recently, Fang \& Zhong (2004) and Larsen (2006) have used a market-based methodology to estimate firms' total asset risk and report strong evidence of risk shifting behavior among industrial firms.

With respect to our first question, the literature has remained largely silent. This paper presents the first systematic evidence on the impact of debt governance on firms' risk-taking behavior. First, we document a significant negative relation between risk shifting and debt governance. Our empirical model estimates that increasing the debt governance proxies from minimum to maximum level is associated with a reduction in the firm's industry-adjusted asset risk of up to $25 \%$ of the level in previous periods. To conduct the analysis, we construct two firm-level debt governance proxies, based on the corporate bond issue-level covenant indices developed in Wei (2006). To measure risk shifting relative to industry peers, we follow the market-based approach adopted in Fang \& Zhong (2004) and Larsen (2006).

We further investigate the impact of debt governance on risk shifting when firms are close to financial distress. Theories predict that risk shifting is more likely when default likelihood is high, and therefore debt governance should play a more important role under such situations. We use two proxies for high default probabilities - a direct estimate of default probability as inferred from

\footnotetext{
${ }^{1}$ Seminal work on this topic includes Jensen \& Meckling (1976), and Smith \& Warner (1979) in the agency literature, and Black \& Scholes (1973), Merton (1974) and Galai \& Masulis (1976) in the option pricing literature.

${ }^{2}$ The contracting technology later evolved to include another type of conflict - event risk (e.g., Crabbe (1991)).

${ }^{3}$ See John, Saunders \& Senbet (2000) for a theory related to risk shifting in financial institutions. Also, see Esty (1997a) for empirical evidence from the savings and loan industry.
} 
the Merton (1974) model ${ }^{4}$ using Moody's KMV algorithm and an indicator of whether the firm is rated speculative. Analysis using either proxy finds strong evidence that debt governance plays a more significant role in controlling the firm's risk shifting behavior among firms close to financial distress. For example, we find that debt governance plays virtually no role in restricting risk shifting when firms have relatively low default risk or are rated investment-grade. Among firms with high default probabilities (or a speculative-grade rating), however, strong debt governance is associated with $25 \%$ (or 27\%) reduction in industry-adjusted asset risk ratio.

With respect to our second question, i.e., the managerial incentives behind the risk shifting problem, we investigate how debt governance interacts with managerial risk-taking incentives in affecting the firm's asset risk and the bond prices. ${ }^{5}$ There is an ongoing theoretical debate on whether option-based compensation will incentivize risk-averse managers to make more risky decisions. ${ }^{6}$ Empirically, a number of studies report a positive relation between the firm's stock volatility and the value and risk incentives embedded in executives' compensation package. ${ }^{7}$ In particular, recent findings by Coles, Daniel \& Naveen (2006) suggest that high risk-taking incentives result in riskier investment and financing decisions.

Moreover, bondholders seem to be concerned with such incentives. For example, Daniel, Martin \& Naveen (2004) find a significantly positive relationship between the credit spreads and the risk-taking incentives of the issuer's CEO compensation. Rating agencies also make statements expressing such concerns: "Since incentive compensation is intended to align manager incentives with stockholder interests, it is reasonable to expect that higher levels of incentive pay (at least based on shareholder-oriented metrics) would be correlated with greater credit risk." (Moody's (2005)).

Using the sensitivity of CEO wealth to stock volatility (Vega) as a measure of managerial risktaking incentives, we further find that strong debt governance significantly mitigates the impact of Vega on risk-increasing decision making. Without strong debt governance, high Vega increases the industry-adjusted asset risk ratio (IRAR) by 7 percentage points, compared to firms with low Vega. With strong debt governance, such impact is reduced to 1 percentage point.

Finally, we find that the impact of Vega on the credit spreads of the firms' public bonds is a function of the strength of firm-level debt governance. Consistent with Daniel et al. (2004), we find that on average credit spreads increase with Vega. By interacting Vega with debt governance proxy, however, we find constrasting effect of Vega on credit spreads, depending on the strength of debt governance. Specifically, credit spreads increase with Vega when debt governance is weak, but

\footnotetext{
${ }^{4}$ See Section 5 for a discussion of using the Leland \& Toft (1996) model as an alternative approach to estimate asset risk and default probability.

${ }^{5}$ The Anglo-Saxon view of corporate governance has mainly focused on maximizing shareholder value via enhancing transparency and strengthening shareholder rights. See Tirole (2001) for a more balanced "stakeholder" perspective. For a comprehensive survey of corporate governance, see Shleifer \& Vishny (1997).

${ }^{6}$ Early papers that suggest option-based compensation as solution to incentivize risk-averse CEOs include, e.g., Haugen \& Senbet (1981), and Amihud \& Lev (1981), etc. Recent theories questioning the earlier argument include, e.x., Ross (2004). Section 2 contains a more detailed discussion.

${ }^{7}$ Examples include Guay (1999), Cohen, Hall \& Viceira (2000), etc. Section 2 contains a more detailed discussion.
} 
decrease with Vega when strong debt governance is in place. The difference due to debt governance is estimated to be as high as 266 basis points per one-million dollar increase in Vega.

The remainder of this paper is organized as follows: Section 2 reviews the related literature. Section 3 describes the data and the estimation method to compute the unobservable asset risk. Section 4 reports the empirical results. Section 5 discusses several robustness issues and Section 6 concludes.

\section{Related literature and hypothesis}

Even three decades after the work by Galai \& Masulis (1976), Jensen \& Meckling (1976), and Myers (1977) analysts, investors, and researchers still examine the conflicts of interest between bondholders and equityholders in levered firms. ${ }^{8}$ The contigent claim approach by Black \& Scholes (1973) and Merton (1974) is a common way to describe the agency problem, where equity is viewed as a residual claim on the firm's assets after all debt obligations are met and is increasing in the underlying asset risk. ${ }^{9}$ Furthermore, the fact that levered equityholders have limited liability and unlimited upside potential provides incentives to increase firm risk by investing in risky positive or even negative net-present-value projects. This risk shifting or asset substitution strategy increases the default risk and extracts wealth from bondholders to equityholders.

The potential risk shifting problem is examined in two recent empirical studies by Fang \& Zhong (2004) and Larsen (2006), where asset risk is inferred using Moody's KMV algorithm in a contingent claim approach. Fang \& Zhong (2004) and Larsen (2006) examine the relation between risk shifting and the firms' default risk and find that firms with high default risk are more likely to increase ex post asset risk, suggesting that managers act in the interest of the equityholders when the firms are in financial distress.

Both papers ignore, however, the conflicts of interest between managers and stockholders and how this may influence the risk shifting behavior. Jensen \& Meckling (1976) and Holmström (1979) show that manager-stockholder conflicts are reduced by relating managerial compensation to firm performance, and Haugen \& Senbet (1981) point out that option-based compensation mitigates the risk-averse manager's reluctance to take risky investment projects (see also e.g., Amihud \& Lev (1981), Smith \& Stulz (1985), Lambert (1986), Hirshleifer \& Suh (1992), and May (1995)). Recent analytical studies show, however, that managerial risk-taking incentives from option-based

\footnotetext{
${ }^{8}$ Other papers investigating the stockholder-bondholder conflicts are Smith \& Warner (1979), Barnea, Haugen \& Senbet (1980), Gavish \& Kalay (1983), Leland (1998), Parrino \& Weisbach (1999), Childs, Mauer \& Ott (2005) among others.

${ }^{9}$ The Merton (1974) model is extended in several ways to weaken some of the restrictive assumptions made in the original model by Black \& Scholes (1973) and Merton (1974). Black \& Cox (1976) allow for default before debt maturity by introducing a constant lower boundary, and Longstaff \& Schwartz (1995) model a more complex debt structure. Tax advantages of debt and bankruptcy costs were introduced by Leland (1994) and refined in Leland \& Toft (1996).
} 
compensation are highly sensitive to certain characteristics of the compensation scheme. When analyzing the risk-averse and undiversified manager's risk incentives in a utility-based model, Lambert, Larcker \& Verrecchia (1991), Carpenter (2000), and Hjortshøj (2006) show that the risk-taking incentives are sensitive to option characteristics such as the option's moneyness, the managers' outside wealth, and the size of the other components of the total compensation scheme. ${ }^{10}$

The managers' and equityholders' risk-shifting incentives are likely to increase the firms' credit risk and lower the wealth of the bondholders. Jensen \& Meckling (1976), Myers (1977), and Smith \& Warner (1979) suggest that including bond covenants in the bond contracts mitigates the bondholder-equityholder conflicts and reduce the default risks. Wei (2006) reviews this literature with an in-depth description of the different covenant protections and how these could restrict the manager's decisions. ${ }^{11}$ The common objective of the different bond covenant types observed in the US market is to constrain ex post managerial decisions in order to reduce the bondholderequityholder conflicts. Theories recognize the cost-benefit tradeoff in choosing covenants. On one hand, with the covenant protection written in the contract, bondholders lower the premium they require for their investment. On the other hand, restrictive covenants might impose costs on the firm if the restrictions limit the firm's operating flexibility to pursue growth opportunities. ${ }^{12}$ Furthermore, Berkovitch \& Kim (1990) point out that, under certain circumstances, restrictions solving under-investment problem might create incentive for excessive investment and vice versa. These trade-offs are generally summarized under the "Costly Contracting Hypothesis".

The empirical literature on debt covenants has been centered on the "Costly Contracting Hypothesis". Researchers typically focus on the issuance time and examine factors that affect the ex ante covenant choices. Consistent with the theoretical predictions, firms are more likely to include restrictive covenants in their debt if they face higher shareholder-bondholder conflicts (e.g., Malitz (1986) and Begley \& Feltham (1999)). On the costs of covenants, several studies report a negative relationship between growth opportunities and the covenant inclusion for public bond issues. ${ }^{13}$ Billet, King \& Mauer (2006), however, apply a simultaneous-equation framework to find a strong positive relation between covenant intensity and growth opportunity. Similarly, Bradley \& Roberts (2004) observe a positive relation between growth opportunities and covenant inclusion in private

\footnotetext{
${ }^{10}$ Other papers examining the risk incentives in a utility-based framework are Hall \& Murphy (2002), Ju, Leland \& Senbet (2002), Johnson \& Tian (2004), Nohel \& Todd (2004), Ross (2004), Brisley (2006), and Lewellen (2006)

${ }^{11}$ Smith \& Warner (1979) describe the Production/Investment, Dividend, Financing and Bonding Covenants. Crabbe (1991) presents the Event-Risk Covenants such as poison put and super poison puts, while Bhanot \& Mello (2006) describe the "Rating Trigger" Covenant.

${ }^{12}$ See, e.g., Jensen \& Meckling (1976), Smith \& Warner (1979) and Berlin \& Mester (1992). For models that focus on specific types of covenants see Myers (1977) on dividend covenants as a solution to the underinvestment problem, John \& Kalay (1982), who model the cost-benefit tradeoff associated with the dividends payout covenant constraints. More recently, Bhanot \& Mello (2006) examine the the cost-benefit tradeoff in choosing "rating trigger clause" (rating decline covenant).

${ }^{13}$ See, e.g., Kahen \& Yermack (1998), Nash, Netter \& Poulsen (2003), Goyal (2005)). A further interesting finding by Kahen \& Yermack (1998) is that convertibility seems to subsitute for covenants when firms face high growth opportunities.
} 
debt contracts.

Studies examining manager's remuneration package find a positive relation between firm's stock return volatility and the convexity of the total compensation scheme (e.g., Guay (1999), Cohen et al. (2000), and Rajgopal \& Shevlin (2002)). Guay (1999) and Coles et al. (2006) find that R\&D intensity and growth opportunities have a positive association with the option's risk incentives and Cohen et al. (2000) and Coles et al. (2006) provide empirical evidence of a positive relation between risk incentives and firm leverage. Furthermore, DeFusco, Johnson \& Zorn (1990) and Hjortshøj (2006) find that option grants have a positive impact on both stock risk and leverage. In addition, Hjortshøj (2006) applies Moody's KMV method to compute the asset risk and finds positive risk shifting in asset risk after stock option grants.

Also analysts in rating agencies such as FitchRatings, Moody's and Standard \& Poor's have expressed concern about the impact from managerial option-based compensation on the firm's credit quality (see, e.g., FitchRatings (2004), Standard \& Poor's (2004), and Moody's (2005)). Moody's Investor Service noted in August 2003: ${ }^{14}$ Executive pay arrangements that provide large short-term incentives - particularly those related to equity valuations, which can be volatile and erratic - may pose excessive risk, particularly from a creditor standpoint.

In sum, following the arguments outlined above we have reasons to believe that managers with a significant part of their total wealth related to the overall firm performance are more willing to make highly risky investments to increase their own expected future gain of the option component. We therefore predict that risk shifting behavior is positively related to executives' risk-taking incentives of option-based compensation. In addition, we expect that high default risk as well as high managerial stock option risk incentives result in greatest risk shifting.

The last branch of literature that is relevant concerns the design of the corporate governance system. To focus on the role of covenants in mitigating the shareholder-bondholder conflicts, Smith \& Warner (1979) start by assuming that managers are perfectly aligned with shareholders, and conclude by recognizing that different agency conflicts should not be viewed in isolation. The Anglo-Saxon view of the corporate governance, on the other hand, focuses on the shareholdermanager conflicts. ${ }^{15}$ Recent evidence suggests that some corporate governance mechanisms viewed favorably by shareholders raises the concerns of creditors. ${ }^{16}$ Although a "stakeholder" perspective has been advocated in the literature (see, e.g., John \& Senbet (1998) on board effectiveness, Tirole (2001) on a unifying framework), explicit considerations of stockholder-bondholder conflicts in the

\footnotetext{
${ }^{14}$ The article is available on www.moodys.com

${ }^{15}$ For a comprehensive survey of this subject, see Shleifer \& Vishny (1997).

${ }^{16}$ See, e.g., Chava, Dierker, Livdan \& Purnanandam (2007) on the relationship between the G index developed in Gompers, Ishii \& Metrick (2003) and the cost of bank debt. Klock, Mansi \& Maxwell (2005) relate G to bondholder prices and show a higher cost of debt with higher shareholder rights. Bhojraj \& Sengupta (2003) study how the existence of institutional investors and outside directors is related to the cost of debt. Cremers, Nair \& Wei (2007) study the interaction between the existence of a blockholder and the level of anti-takeover protection in the firm's charter provisions. They document that the two mechanisms complement each other in increasing the effective takeover vulnerability of the issuer, and thus increase the cost of debt.
} 
corporate governance literature are rare. ${ }^{17}$ Empirically, the evidence suggests that bondholders are concerned about the higher managerial incentives provided by the managerial compensation. Different studies find consistent evidence using different measures of managerial incentives and different methodologies. ${ }^{18}$ Most relevant to our analysis is Daniel et al. (2004), who document a positive relationship between the credit spreads and the Delta and Vega of CEOs' total portfolio of stock and options.

\section{Data and Construction of the Proxies}

In this section, we describe the data sources and measure construction, which can be separated into six categories - data for (1) risk shifting, (2) default risk, (3) debt governance, (4) managerial incentives, (5) bond prices and rating and (6) firm characteristics. Following Fang \& Zhong (2004), Vassalou \& Xing (2004), and Larsen (2006) we exclude financial firms, utilities, and all equity firms. ${ }^{19}$

\subsection{Asset risk and industry-adjusted risk adjustment ratios}

In the recent credit risk literature, Moody's KMV method, described by Crosbie \& Bohn (2003), has become a popular iterative algorithm for estimating the unobserved asset risk. We follow the implementation of Moody's KMV method by Vassalou \& Xing (2004), where the equity is modeled as a Merton (1974) European call option on the firm's assets. ${ }^{20}$ The face value of the firm's debt (the strike price) is defined as the current liabilities plus half the long-term debt, and the debt maturity is assumed to be one year. ${ }^{21,22}$ The daily market values of equity are computed as the number of shares outstanding multiplied by the closing price or the bid/ask average. We choose the risk-free interest rate as the constant maturity 1-year Treasury Bill rate and for the asset payout rate we follow Huang \& Huang (2003) and use 6 percent.

We use equity prices of the past 12 months from CRSP to calculate an initial guess of the asset

\footnotetext{
${ }^{17}$ One exception is John \& John (1993), who are the first to consider risk-shifting incentives in the design of an optimal managerial compensation structure.

${ }^{18}$ For example, DeFusco et al. (1990) and Hjortshøj (2006) study the announcement effect of new option grants. Bagnani, Milonas, Saunders \& Travlos (1994) study the relation between bond return premium and managerial ownership using a regression approach.

${ }^{19}$ Financial firms and utilities are generally considered as tightly regulated and this may result in a risk shifting behavior unrelated to the bondholder-equityholder conflicts.

${ }^{20}$ Crouhy, Galai \& Mark (2000), Bharath \& Shumway (2004), Duan, Gauthier \& Simonato (2004), Fang \& Zhong (2004), Reisz \& Perlich (2004), Sundaram \& Yermack (2005), and Larsen (2006) all implement Moody's KMV algorithm in a similar way as Vassalou \& Xing (2004).

${ }^{21} \mathrm{~A}$ more detailed description of the Merton (1973) model is given in Appendix A.

${ }^{22}$ We follow Larsen (2006) and use COMPUSTAT financial data from the end of the previous financial year as our current year measure of debt. The current liabilities include the total amount of short-term notes and the current portion of long-term debt that matures in one year. Fang \& Zhong (2004) and Vassalou \& Xing (2004) find that their results are robust for other choices of weights on the long-term debt.
} 
volatility and apply the iterative algorithm to compute daily asset values. In order to have sufficient liquidity in the market prices of equity we require at least 100 daily equity prices per calendar year. Those computed asset values allow us to calculate a new estimate of the asset volatility, which we use as the input parameter in the next iteration. The algorithm is repeated until we obtain convergence of asset volatility estimates from two consecutive iterations. ${ }^{23}$ We fix outliers by winsorizing the equity volatilities, the asset volatilities, and the drift at the 1st and 99th percentiles.

In order to examine the ex post unanticipated risk shifting we follow Skinner (1989) and Brown, Harlow \& Starks (1996) and calculate a risk adjustment ratio $\mathrm{RAR}_{\mathrm{t}}=\sigma_{V}^{t+1} / \sigma_{V}^{t}$, where $\sigma_{V}^{t}$ and $\sigma_{V}^{t+1}$ denote the current and the next year's asset volatility, respectively. To filter out industry-wide factors we follow Fang \& Zhong (2004) and Larsen (2006) and calculate an industry-adjusted risk adjustment ratio $\left(\operatorname{IRAR}_{t}\right)$, where we subtract the median $\mathrm{RAR}_{t}$ of the firms with the same 2-digit SIC coded industry and in the same year. Throughout the rest of our analysis we use $\mathrm{IRAR}_{\mathrm{t}}$ to examine the levered equityholder's risk taking behavior.

\subsection{Default risk}

According to Myers (1977), firms that are in financial distress are most exposed to agency problems since the equityholders face limited downside but unlimited upside potential. In other words, when the firm is on the verge of bankruptcy everything is to be gained and nothing lost.

Consistent with the existing literature, we use a market-based measure of the default probability based on Moody's KMV method. Competing accounting-based measures, such as the Z-Score derived by Altman (1968) and the O-Score derived by Ohlson (1980), are shown to have less predictive power than the market-based measure in a recent study by Hillegeist, Keating, Gram \& Lundstedt (2004).

Based on the Merton (1974) model the default probability is the probability that the market value of assets, $V$, is less than the strike, $X$, (the current liabilities plus half the long-term debt) maturing in one year.

$$
D P_{t}=N\left(-\frac{\ln \left(V_{t} / X_{t}\right)+\left(\mu_{V}-\frac{1}{2} \sigma_{V}^{2}-\delta_{V}\right) T}{\sigma_{V}}\right),
$$

where $\mu_{V}$ is the continuously compounded expected annual return on assets, $\delta_{V}$ is the average historical payout rate, and $T$ is the one year default horizon. ${ }^{24}$

As pointed out in Vassalou \& Xing (2004) our proxy for default risk differs from those inferred by Moody's KMV since we use a normal distribution whereas Moody's KMV uses an empirical distribution of defaults to compute the default probabilities.

\footnotetext{
${ }^{23} \mathrm{We}$ assume a level of convergence of $1.0 \mathrm{E}-4$.

${ }^{24}$ Assuming that the market value of assets is normally distributed allows us to compute the real world drift $\mu_{V}$ from the last time-series of daily asset values.
} 
By definition, $\mathrm{DP}_{t}$ is a model-specific measure based on the Merton (1974) model, which uses equity market data as the model input. Alternatively, we can rely on the assessment of rating agencies to capture situations of high default probability. The advantage of using firm credit rating assigned by rating agencies is that it reflects the direct assessment of a company's default likelihood, based on credit-sensitive information processed by third parties. ${ }^{25}$

\subsection{Debt Governance: Issue- and Issuer-level Covenant Protection Index}

The main data source used for measuring debt governance is the Mergent Fixed Investment Securities Database (FISD). FISD contains issue details on over 140,000 Corporate, Corporate MTN (Medium Term Note), Supranational, U.S. Agency and U.S. Treasury debt securities. Among more than 550 data fields, the FISD database provides detailed information on the bonds at the time of issuance, including offering yield, offering amount, coupon type/rate, maturity, callability and putability features etc. A unique feature of FISD is the comprehensive coverage of the bond indenture provisions. The sources for this information are bond prospectus, issuers' SEC filings including 10-K, 8-K, registration forms, etc.

We focus on non-convertible bonds issued in the post-1990 period in which the coverage becomes comprehensive. ${ }^{26,27}$ FISD provides data on the incidence of more than 40 covenants. For issue-level debt governance measures, we use the $\mathrm{J}$ and $\mathrm{W}$ indices developed by Wei (2006). These two indices are constructed using 28 covenants grouped into the following five categories - Production/Investment (Investment), Dividend, Financing, Default-related (Default) and Event-related (Event). ${ }^{28}$ Briefly, $\mathrm{J}$ is the total number of covenants in each contract (see, e.g., Gompers et al. (2003)), and W captures the number of the categorization of conflicts addressed by covenants as in Smith \& Warner (1979).

To develop a firm-level aggregate measure of the strength of public debt governance, we weight the $\mathrm{J}$ or $\mathrm{W}$ index of each issue by its outstanding amount in each period, and compute a weighted average of $\mathrm{J}$ or $\mathrm{W}$ indices of all outstanding bonds,

$$
C o v_{-} W_{i}^{t}=\frac{\sum_{j=1}^{M} W_{i j}^{t} B_{i j}^{t}}{\sum_{j=1}^{M} B_{i j}^{t}},
$$

\footnotetext{
${ }^{25}$ We use rating data from both Moody's and S\&P. When the two rating agencies' assessment don't agree, we take the average of the two. Mansi \& Reeb (2002) suggest that using the average of both Moody's and S\&P provides the most efficient measure of the default risk premium. We apply their methodology in a slightly different context here.

${ }^{26}$ For each issue, FISD provides an indicator on whether detailed covenant information is collected for that issue. For bonds issued in the post-1990 period, about half have missing covenant information and are therefore excluded from our study. Billet et al. (2006) find that whether a bond issue has covenant information is not a function of when a bond is issued during the year, the priority, rating or maturity of the bond, the size of the issue or the issuer, the exchange on which the issuer's stock trades.

${ }^{27}$ Smith \& Warner (1979) suggest, and Kahen \& Yermack (1998) empirically confirm, that the convertibility feature might substitute for covenant protection, especially when the issuer has good growth opportunities.

${ }^{28}$ See Appendix B for descriptions of each provision. Wei(2006) gives detailed description on the construction of each measure.
} 
where $W_{i j}^{t}$ is the covenant index of firm $i$ 's corporate debt issue $j$ with the outstanding amount $B_{i j}$ at time $t$. We apply the same formula to the $\mathrm{J}$ covenant indices of the firm's outstanding bonds, to reach an aggregate Cov__ $J_{i}^{t}$. For measurement easiness, we also standardize the two indices using the sample standard deviation of each to reach two scaled measures - Scale__ $J_{i}^{t}$ and Scale_$W_{i}^{t}$. Appendix B provides a detailed description of the different covenant provisions.

One rationale behind using the outstanding amount as the weight is that it captures the relative easiness to remove the covenant restriction by retiring or restructuring the debt issue. ${ }^{29,30}$

\subsection{Managerial Incentives}

To measure CEO incentives, we follow recent literature (e.g., Coles et al. (2006)) to construct two measures. Delta is the change in the dollar value of the executive's wealth for a one-percentage point change in stock price. Vega is the change in the dollar value of the executive's wealth for a change of one percentage point in the annualized standard deviation of stock returns. The calculation follows Guay (1999) and Core \& Guay (2002), who use the Black-Scholes option valuation model. See Appendix C for a detailed description.

We use the Standard and Poor's Execucomp database for data on CEO compensation. Execucomp provides data on salary, bonus and total compensation for the top five executives (ranked annually by salary and bonus) of firms in the S\&P 500, S\&P Midcap 400, and S\&P Smallcap 600, for the period 1993-2002.

\subsection{Corporate Bond Prices and Bond Ratings}

Data of secondary market prices of corporate bonds is not easily available. To maximize the sample size and therefore the power of the empirical tests, we collect corporate bond prices from three sources. Our first source is the Lehman Brothers' Bond Database (LBBD), which has been a major data source for corporate bond prices (yields) in previous bond pricing literature (see, e.g., Elton, Gruber, Agrawal \& Mann (2001)). LBBD reports the institutional pricing for Treasury and corporate bonds. The dataset contains both matrix prices as well as dealer quotes, and we only use dealer quotes. ${ }^{31}$ Finally, LBBD also provides information on some issue characteristics such as issue size, maturity, callability, seniority and credit ratings which we use as controls in our regression model in Section 4.3.2. ${ }^{32}$

\footnotetext{
${ }^{29}$ In investigating contracting decisions, Billet et al. (2006) construct a measure similar to the aggregate J index in this study.

${ }^{30}$ Covenant defeasance is another legal procedure by which firms can be freed from the restriction. However, this is relatively rare in public bonds (see e.g., Kahen \& Tuckman (1993)). Renegotiation is another approach to modifying contract terms, but it is usually only feasible for closely held private debt contracts.

${ }^{31}$ Matrix prices are set according to some pricing algorithm based on bonds with similar characteristics, whereas dealer quotes directly reflect market participants' evaluation. Matrix prices are regarded as less reliable than actual dealer quotes (see, e.g., Warga \& Welch (1993), and Elton et al. (2001)).

${ }^{32}$ See the description in 8 of the controls used in the regression model.
} 
We focus on bonds with Standard and Poor's and Moody's credit ratings between AA+ (Aa1) and B- (B3). ${ }^{33}$ AAA (Aaa) bonds in both LBBD and NAIC datasets have appeared "problematic" in previous studies (see, e.g., Elton et al. (2001)), and we follow the literature to exclude bond observations with AAA (Aaa) ratings. We also remove high yield bonds rated CCC+ (Caa1) or below, because there are not enough observations for bonds below $\mathrm{CCC}+$, and there are potential problems that the prices of these bonds are more likely to contain errors due to infrequent trading/quoting. We keep speculative-grade bonds above B- (B3), however, because covenant incidence usually increases with the risk of the bonds, and it is important to keep reasonable variation in the covenant indices for the purpose of this study. To ensure that the high yield bond prices are representative of the market, we only focus on the month in which at least 10 bond transactions are observed among the insurers. We then pick the price of the transaction that is closest to the end of month.

The risk-free term structure of interest rates is from the Salomon Brothers Yield Book, including the quarterly treasury benchmark yields with time-to-maturity of 1, 2, 3, 5, 10, 20 and 30 years. To calculate the credit spreads of each observation, we match by time-to-maturity to get the corresponding Treasury benchmark yield and adjust the bond yield with the corresponding risk-free interest rates. We use linear interpolation to calculate Treasury yields with time-to-maturity of other years below 30. For the few observations with time-to-maturity of more than 30 years, we use the 30-year Treasury benchmark. For each observation, the spread is calculated as the difference between the bond yield and its corresponding Treasury benchmark. The term structure of interest rate is also used to control the impact of the term structure in the credit spread regression.

Finally, when rating information is not available in LBBD or FISD, we use Moody's Default Research Data and S\&P's CreditPro Database as additional sources of issue- and issuer-level rating histories.

\subsection{Control variables}

Consistent with Coles et al. (2006) we use Surplus Cash as a proxy for the amount of cash available, where free cashflow is usually associated with relatively safe and mature firms with low investment opportunities (see, e.g., Jensen (1986)). We therefore expect a negative relation between Surplus Cash and risk taking.

Tangible assets are generally viewed as more reliable collateral for secured debt and helps in case of default. Begley \& Chamberlain (2005) find a negative relation between tangible assets and the use of protective covenants and suggest that more tangible assets indicate lower likelihood of corporate default. Therefore, more tangible assets result in better creditor perspective on recovery, which suggests lower credit risk and risk taking incentives. Furthermore, more tangible assets

\footnotetext{
${ }^{33}$ See footnote 25 for a description of the selection of rating controls.
} 
usually mean more mature firms with less growth opportunities and therefore less room for ex post risk taking. We expect a negative relation between Tangibility and risk taking.

Jensen \& Meckling (1976) suggest that more growth opportunities may increase the overinvestment problems since high growth firms are more likely to have risky investments left in their investment opportunity set. In addition, Kahen \& Yermack (1998) and Nash et al. (2003) find that high growth firms tend to include less restrictive covenants and argue that high growth firms value their investment opportunities and investment decision flexibilities more (see also, e.g., Bradley \& Roberts (2004), and Goyal (2005)). We use Market-to-book ratio as a measure of investment opportunities and predict a positive relation between risk taking and Market-to-book ratio.

We also need to control for the leverage since Malitz (1986) and Bradley \& Roberts (2004) find that firms with more leverage use more restrictive covenants and Chava \& Roberts (2006) report a negative relation between book leverage and investments. ${ }^{34}$ We follow the measure of Book Leverage by Coles et al. (2006) and expect to find that higher leverage results in less risk taking.

Finally, we follow Fang \& Zhong (2004) and Larsen (2006) and control for Firm Size, and we use Asset Risk to capture the predicted inverse relation between IRARs and current asset volatility. Parrino \& Weisbach (1999) emphasize that highly volatile firms are more likely to have less risky projects left in their investment opportunity set. Nohel \& Todd (2004) and Parrino, Poteshman \& Weisbach (2005) argue that the managers may reduce firm risk to lower the probability of financial distress and to safeguard the interests of their own career concerns. In addition, the mean-reversion in firm risk could be another plausible explanation for the inverse relation between current asset volatility and risk shifting (e.g., Stein \& Stein (1991), and Heston (1993)).

Appendix D provides a detailed description of the variable definitions.

\section{Empirical Analysis}

In this section, we document (1) the impact of debt governance on firms' risk shifting behavior and how this effect depends on the firm's default likelihood, and (2) how debt governance mitigates the impact of managerial risk-taking incentives on risk shifting and bondholder value.

We start by presenting some summary statistics of the data. Panel A of Table 1 shows the distributional statistics of three key variables inferred from the Merton (1974) model using Moody's KMV algorithm - asset risk adjustment ratio (RAR), industry-adjusted RAR (IRAR) and modelimplied default probability (DP). Overall, we have 9770 firm-year observations which have nonmissing data on risk measures, debt governance measures and control variables. On average, firms increase their asset risk by $5 \%$ from the previous period. However, the sample median RAR indicates that more than half of the time firms are reducing asset risk. For IRAR, the risk shifting activities

\footnotetext{
${ }^{34}$ See Childs et al. (2005), Purnanandam (2005), and Bhanot \& Mello (2006) for a theoretical investigation of levered equityholders' risk-shifting incentives.
} 
of the firms in our sample are on average above their industry median, but the sample median IRAR suggests the opposite. Our sample firms have on average an estimated default probability of $5.7 \%$ and a much lower median DP of virtually zero. This is consistent with the fact that corporate bond issuers tend to be larger in size and less prone to default. Lastly, it is important to note that all three measures have reasonable variation in our sample.

Summary statistics of the debt governance measures are presented in Panel B. The firm-level outstanding-amount-weighted Cov_J (Cov_W) index ranges from 0 to a maximum of 17.3 (5), with a mean of $6.04(3.12)$ and a standard deviation of 3.31 (1.30). The standardized versions of the two are also presented.

Panel C presents the summary statistics of the risk-taking incentive - Vega, derived from the CEO's compensation package. For a one-percentage point increase in the company's stock volatility, there is an average of 146.5 thousand dollar increase in the CEO's compensation. This number is larger than what is reported in a recent study by Coles et al. (2006), which focuses on the full universe of the Execucomp database. Again, the difference might reflect the fact that we are focusing on firms that are large enough to have access to the public debt market. Lastly, summary statistics on the control variables are reported in Panel D.

\section{[Insert Table 1]}

Table 2 presents the time series pattern of the risk shifting and the debt governance measures. Panel A and Panel B of Table 2 show the mean and median RARs and IRARs per calender year, along with number of companies in each period. We first notice that the mean and median RARs are comparable to those presented in studies by Fang \& Zhong (2004) and Larsen (2006). ${ }^{35}$ The RAR measure stays stable in the early part of the 90 's and then becomes volatile after 96 . The pattern of IRAR shows that the risk shifting levels of our sample firms are below their industry median level at both ends of the sample period, but stay above during the latter half of the 90s. In terms of debt governance, Panel C shows an upward trend in debt governance level in the 90s. The levels peaked around 1999 and then declined.

\section{[Insert Table 2]}

Figure 1 visualizes the time variations of three key variables - Cov_J, Cov_W and IRAR. Plotted in each panel are annual mean and median levels of Cov_J (Panel A), Cov_W (Panel B) and IRAR (Panel C). According to both statistics, the debt governance measures have been gradually increasing in the 90's, peaking around 1999 and decreasing ever since. The pattern of the industry adjusted relative risk shifting measure (IRAR) is less obvious. With the first half of

\footnotetext{
${ }^{35}$ For comparison purposes, we also looked at the median level of RAR in the Compustat universe and compared it with results from our sample. We observed slightly higher level of RAR in the Compustat sample, but the time series patterns of the two samples are comparable. These results are available upon request.
} 
90's seeing a gradual increase in IRAR, the latter half sees a decrease. IRAR appears to be more volatile after 2000 .

[Insert Figure 1]

Table 3 reports the correlation matrix of IRAR, DP, Asset Risk, Scale_J, Scale_W and some firm characteristics. The negative correlation between IRAR and Asset Risk is consistent with Fang \& Zhong (2004) and Larsen (2006). Not surprisingly, the two debt governance measures are highly correlated. The positive correlations between DP and the debt governance measures reflect the fact that high yield debtholders choose stronger governance by including more covenants, due to the much higher default likelihood. With respect to the correlation between the key variables and the firm characteristics, the results are generally consistent with findings in recent studies such as Fang \& Zhong (2004) and Larsen (2006). We now proceed to report the main empirical analysis using regression framework.

\section{[Insert Table 3]}

\subsection{Risk Taking and Debt Governance}

We first document the impact of debt governance on firms' risk shifting behavior. In the regression analysis that follows, we implement the Fama \& MacBeth (1973) approach by running annual crosssectional regressions and report the time-series averages of the parameter estimates. Consistent with Jin, Merton \& Bodie (2006) we correct the time-series standard errors for serial correlation by using the procedures in Pontiff (1996) and Abarbanell \& Bernard (2000). ${ }^{36}$

Table 4 reports the results from the Fama \& MacBeth (1973) regression of annual risk shifting measure IRAR on debt governance variables Scale_J and Scale_W plus the firm-specific control variables. In each annual cross-section regression, we control for Surplus Cash, Tangibility, Marketto-book ratio, Book Leverage, Firm Size (log of asset) and Asset Risk. ${ }^{37}$ Coefficient estimates on control variables are generally consistent with recent studies. Regarding the debt governance proxies, Model 1 and 2 show that both Scale_J and Scale_W have strongly negative and significant coefficients, equal to -0.25 with a t-stat of -2.86 for Scale_J, and -0.17 with a t-stat of -2.52 for Scale_W. These results show that the presence of strong debt governance is associated with significant reduction in the asset risk, as measured by IRAR.

\footnotetext{
${ }^{36}$ Pontiff (1996) and Abarbanell \& Bernard (2000) adjust the time-series standard errors for serial correlation by modeling the residuals as an autoregressive process. In our empirical analysis we regress the time-series of the parameter estimates on an intercept term and model the residuals as a first-order autoregressive process. We find that the adjusted standard errors are identical to the unadjusted standard errors since the empirical estimates on the first-order autocorrelation term is statistically insignificant.

${ }^{37}$ See Appendix D for a detailed definition and a description of the data used for computation.
} 


\section{[Insert Table 4]}

The observed effects are also economically important. For example, moving from the minimum (0) to the maximum (1) level in the debt governance index Scale_J (Scale_W), the associated reduction in asset risk ratio $\sigma_{V}^{t+1} / \sigma_{V}^{t}$, is $25 \%(17 \%)$ relative to the firm's industry median.

We further investigate how nonlinearity could affect our results. Since we use noisy measures of debt governance, imposing a linear relationship between the estimated risk shifting measure and the debt governance proxies might be improper. In Model 3 and 4, we specify a piece-wise linear relationship using quartile dummies for Cov_J and Cov_W. The results indeed suggest a non-linear relationship. For example, relative to the lowest level (quartile 1) of debt governance, the impact of debt governance becomes significantly different only when the Cov_J or Cov_W is above the sample median. In Model 3, everything else being equal, moving from the lower two quartiles of the Scale_J index value to the upper two quartiles results in an $8 \%$ reduction in IRAR. Model 4 using Scale_W yields statistically and economically similar results.

Results in Table 3 confirm a strong negative relationship between risk shifting and debt governance. However, the evidence is consistent with at least two competing explanations. Financial contracting theories predict a causal relationship where strong debt governance (covenant restriction) restrict the manager from making risky decisions that result in a transfer of wealth from senior claimholders to the equityholder. Alternatively, risk level and contracting are both endogenous variables which can be driven by some unobserved factors. To find further support for a causal relationship, we next investigate situations where risk shifting is predicted to be severe.

\subsection{Risk Taking, Default Risk and Debt Governance}

In this section, we explore the nature of debt governance's impact on risk shifting, by conditioning on whether the firm is close to financial distress. We use two proxies for closeness to financial distress - model-implied default probability (DP) and firm credit rating. Since firms close to financial distress are more likely to engage in risk shifting, we expect strong debt governance to play a more significant role when default probability is high.

Table 5 presents results using DP. We sort firms into quartiles with respect to their default probability DP, and define a "high" DP dummy, DP_quar4, for the upper quartile group. We also independently sort firms into two groups according to the strength of debt governance (strong and weak), and define a dummy Cov_J_h (Cov_W_h) for the firms with strong Cov_J (Cov_W). We regress IRAR on DP_quar4, Cov_J_h (or Cov_W_h), an interaction term of the two, and controls for firm characteristics. The estimate for DP_quar4 is 0.20 in both Model 1 and Model 2. Although the economic magnitude of these estimates are comparable to recent findings in Fang \& Zhong (2004) and Larsen (2006), neither is statistically significant. However, we obtain estimation 
results of economic and statictical significance that are comparable to Fang \& Zhong (2004) and Larsen (2006), when the regression is applied to the full COMPUSTAT-CRSP universe. A possible reason for the difference is that our sample of corporate bond issuers tend to be populated with large, mature and hence safer firms, resulting in less variation in DP. The interaction term between dummies for high DP and high debt governance is strongly negative for both debt governance measures, having point estimates of -0.25 with t-stat of -2.09 in Model 1 (DP_quar4*Cov_J_h) and -0.25 with t-stat of -2.06 in Model 2 (DP_quar $4{ }^{*}{ }_{\text {Cov_W_h }}$ ). Lastly, the coefficient estimates for Cov_J_h and Cov_W_h have the expected signs but are statistically insignificant. The results suggest that, although strong debt governance on average does not significantly affect risk shifting when default probability is high, the risk shifting is significantly reduced in the presence of strong debt governance. The economic magnitude of the results seems meaningful. Both models suggest that, for a "high default probability" firm, strong debt governance is associated with a $25 \%$ reduction in risk shifting measure IRAR, as compared to either default-prone firms with weak debt governance, or firms that are default-remote.

\section{[Insert Table 5]}

Table 6 presents corroborating evidence using credit rating as alternative measures for default likelihood. Following Section 4.1, we apply the Fama \& MacBeth (1973) regression in two subsamples - firms that are rated investment and firms that are rated speculative grade by the rating agencies. By definition, the latter case corresponds to firms that have distinctly higher default probability and therefore are more likely to engage in risk shifting activities.

\section{[Insert Table 6]}

Table 6 shows that the impact of debt governance is indeed more significant among speculativegrade firms. In fact, neither debt governance measure has significant coefficient estimate in any of the regressions applied to investment-grade firms (Panel A). On the contrary, Panel B shows that the coefficient estimate for Scale_J is -0.27 with a t-stat of -2.10 in Model 3, and the coefficient estimate for Scale_W is -0.20 with a t-stat of -2.20 in Model 4. Among speculative-grade firms, the reduction in risk shifting due to debt governance is estimated to be $(1-0) *(-0.27)=-27 \%$ using the Scale_J index, and $(1-0) *(-0.20)=-20 \%$ using the Scale_W index.

Recent evidence in Fang \& Zhong (2004) and Larsen (2006) shows that, consistent with the agency theories, risk shifting (measured by IRAR) behavior is most prominent among firms with high default probabilities. Results in this section echo this evidence in that debt governance exerts significant control on firms' risk shifting behavior, precisely under the situations in which this agency conflicts are predicted to be most severe. 


\subsection{Managerial Incentives and Debt Governance}

In this section, we consider the managerial incentives behind the risk shifting problem. Recent evidence by Coles et al. (2006) indicates that higher CEO risk-taking incentives (measured by the sensitivity of CEO wealth to stock volatility, Vega) give executives incentives to engage in more risky corporate policies. Moreover, this effect seems to be reflected in the value of debtholders' investment as well. Daniel et al. (2004) report that higher Vega on average is associated with significantly higher credit spreads, reflecting concerns of the bond investors. In this section, we investigate the role of debt governance in mitigating the aforementioned effects due to high managerial risk-taking incentives, by interacting debt governance and the CEO Vega measure in the regression framework.

\subsubsection{Risk Shifting, Managerial Incentives and Debt Governance}

Table 7 presents Fama \& MacBeth (1973) regression results. To account for nonlinearity in the specification, we again sort firms into quartiles with respect to the Vega measure, and associated a dummy, Vega_quar4, for the upper quartile group. We regress IRAR on Vega_quar4, debt governance dummy Cov_J_h or Cov_W_h, an interaction term of Vega and Cov_J_h or Cov_W_h, and controls. ${ }^{38}$ Model 1 presents evidence consistent with findings in Coles et al. (2006) - Vega is significantly positively associated with risk shifting. Model 2 and 3 investigate the interaction between debt governance and Vega. Model 2 shows that, when Vega is high, strong debt governance significantly mitigate the overall impact of the risk-taking incentives on risk shifting measure IRAR. For example, for firms with weak debt governance, moving from low Vega to high Vega is associated with 7 percentage point increase in the industry-adjusted asset risk ratio. In the presence of strong debt governance, however, increasing Vega from low to high level is only associated with a 1 percentage point increase in IRAR.

Interestingly, Model 3 shows that, when using Cov_W_h to proxy for debt governance, its interaction with Vega becomes insignificant, although the economic magnitude remains similar to that of Model 2. This result highlights the different aspects of debt governance captured by the Cov_J and Cov_W indices. While the former measures the covenant intensity by the weighted average number of covenant provisions in the public debt structure, the latter measures the strength of debt governance in terms of weighted number of categorization of conflicts addressed by the covenants. Perhaps, the categorization is imperfect and the covenant intensity with each category might be more important than the number of conflict categories. We leave this question for future exploration and end this section with the conclusion that the evidence suggests that debt governance plays an important role in mitigating the impact of managerial risk-taking incentives on firms' risk shifting behavior.

\footnotetext{
${ }^{38}$ We consider Fang \& Zhong (2004), Larsen (2006) and Coles et al. (2006) in selecting the control variables.
} 


\section{[Insert Table 7]}

\subsubsection{Credit Spreads, Managerial Incentives and Debt Governance}

If debt governance effectively restricts risk shifting decisions by incentivized CEOs, bondholders would be the first beneficiary group, which should be reflected in market prices. In this section, we directly test this implication by analyzing how managerial incentives and debt governance interact to affect the credit spreads.

The regression framework follows that of Daniel et al. (2004), with two additional explanatory variables - debt governance index Cov_J (or Cov_W) and the interaction between Cov_J (or Cov_W) and Vega. We control firm characteristics including Firm Size, Market-to-Book, lagged stock return, stock volatility, ROA, leverage, interest coverage, and issue characteristics including coupon, time to maturity, issue size, and callability. Lastly, we control for credit ratings using rating dummies for the finest rating classification.

We first present summary statistics of the variables, in Panel A of Table 8. After merging the datasets of bond price, debt governance indices and managerial incentives, our final sample contains more than 29,000 bond months with on average more than 150 firms per month. The mean (median) Delta is $0.44(0.19)$ million dollars with a standard deviation of 0.77 million dollars, and the mean (median) Vega is 0.08(0.05) million dollars with a standard deviation of 0.09 million dollars. Debt governance measure Cov_J (Cov_W) has a mean level of 4.6 (2.4) with a maximum of 14 (5). Controls for firm characteristics (e.g., Market size and leverage) are again representative of large firms. The average time to maturity of the bonds is 13.8 years and the average coupon is $8.2 \%$. Lastly, about $25 \%$ of the bond months represent callable bonds, and $10 \%$ of the bond observations have a speculative credit rating.

Panel B in Table 8 presents the Fama-MacBeth regression results. ${ }^{39}$ Model 1 presents results using Delta and Vega only, that is consistent with Daniel et al. (2004). Delta and Vega are both significantly positively associated with credit spreads. A one-million dollar increase in Vega (Delta) is associated with an increase of 26 (1) basis points in credit spreads. In Model 2, the impact of Vega on credit spreads is decomposed into two parts - the Vega term having a coefficient estimate of 0.97 with a t-stat of 7.01 , and the Vega*Cov_J interaction term having a coefficient estimate of -0.19 with a t-stat of -5.69 . These results suggest a contrasting effect of managerial risk taking

\footnotetext{
${ }^{39}$ For sake of space, only results for the key variables are reported. Coefficient estimates for all the controls are consistent with existing work such as Daniel et al. (2004) and Cremers et al. (2007). The results are available upon request.
} 
incentives on credit spreads, depending on the strength of debt governance. For example, for issuer with weak debt governance (Cov_J=0), a one-million dollar increase in Vega is associated with an increase of $97+0^{*} 1=97$ basis points in credit spreads. With the maximum level of debt governance (Cov_J=14) in place, however, the combined effect is $97+(-19) * 14=-169$ basis points. Overall, depending on the strength of debt governance, the difference in the impact of changing Vega by one million dollar on credit spreads, can be as large as $97-(-169)=266$ basis points. Model 3 delivers similar message using debt governance index Cov_W. Both Model 2 and 3 suggest that the coexistence of strong debt governance and strong managerial risk-taking incentives are viewed positively by the bondholders. Strong managerial risk-taking incentives without the protection from strong debt governance, however, is not priced favorably in the bond market.

\section{[Insert Table 8]}

Agency theories predict that higher managerial incentives could be good or bad news for bondholders. Because of the shareholder-bondholder agency conflict, bondholders require covenants in the bond indenture to protect them from opportunistic behavior of the manager who is on the shareholders' side. Theories predict that, with effective protection, the beneficial side of managerial incentives, i.e., to accept positive NPV projects, should be reflected in higher bond prices. Results presented in Table 8 are consistent with this view. From the bondholders' perspective, high managerial incentives and strong covenant protection work as complements. ${ }^{40}$ From the perspective of firm value maximization, results in this section further suggest that the complementarity results might also apply to the firm as a whole. In particular, to the extent that higher Vega increases the firm's risk taking, as recently documented in Coles et al. (2006), our findings suggest that debt governance might help mitigate the risk shifting component in CEO risk-taking incentives. However, the implications of our results for the firm value are at best indirect, and we leave this issue for future research.

\section{Robustness Checks}

The analysis discussed so far employs a variant of the method of Fama \& MacBeth (1973). A logical alternative is a panel setup with firm fixed effect and time-varying coefficients. However, due to the relative stableness of our debt governance measures, using firm fixed effect will force the identification of the debt governance coefficients from those few cases of within-firm changes through time. On the other hand, as pointed out by Gompers et al. (2003), Fama \& MacBeth (1973) method essentially assumes a fixed firm effect linear in the debt governance measure. To

\footnotetext{
${ }^{40}$ This is consistent with findings in Cremers et al. (2007), who show that takeover-related bond covenants protect bondholders from the negative impact of enhanced takeover vulnerability.
} 
eliminate concerns that the results are sensitive to this assumption, we also conduct panel regression with year and industry effects, to all the empirical tests. The results are qualitatively similar and are available upon request.

Secondly, the risk shifting measures are market-based estimates derived from Merton (1974), which itself could be criticized for not incorporating a number of more realistic factors. In the Merton (1974) framework, the firm has one issue of zero-coupon bond. At maturity of the bond, equityholders will either pay bondholders the face value of the bond or declare bankruptcy and leave the remaining assets to the bondholders. This very simple model has lead to several theoretical extensions that account for more realistic capital structure and allow for intermediate default, among other things. ${ }^{41}$ In order to examine the risk adjustment ratio's sensitivity to our model choice, we calibrate the Leland \& Toft (1996) model and calculate RARs and IRARs, where the structural model by Leland \& Toft (1996) incorporates bankruptcy costs, tax advantages for issuing debt and endogenous default boundary. ${ }^{42}$ We find that the Spearman rank correlation between the RARs (IRARs) inferred from the Merton (1974) model and the Leland \& Toft (1996) model is 0.963 (0.955) emphasizing that our results are highly insensitive to the model choice. ${ }^{43}$

Similarly, the debt governance proxies are likely to be noisy measures. We further experiment with alternative measures by counting up covenants directly addressing corporate actions that are likely to be used in risk shifting - covenant restricting leverage increase, investment, mergers. This measure, which we term as Jrisk, is highly correlated with Cov_J. When we use it in place of Cov_J in all regression analysis, we find qualitatively similar results. However, the statistical significance is reduced in some cases, suggesting those covenants we exclude from Jrisk measure might play an indirect role in mitigating risk shifting. Tables for these results are available upon request.

Lastly, we experiment with different definition of our control variables, to further ensure the robustness of the results. The results are robust with respect to using book or market leverage, and are insensitive to using the original controls of Fang \& Zhong (2004) and Larsen (2006), or an expanded set of controls including those in Coles et al. (2006).

\section{Conclusion}

We investigate the impact of debt governance on firms' risk shifting behavior. Using newly constructed firm-level covenant indices as debt governance proxies, and market-based estimates of asset risk using Moody's KMV algorithm, we find that stronger debt governance is associated with

\footnotetext{
${ }^{41}$ See Lando (2004) for a careful description of the different structural models.

${ }^{42}$ Consistent with Ericsson, Reneby \& Wang (2006) we use a tax rate of $20 \%$ which reflects the personal benefits of equity returns. The bankruptcy costs are 15\% which lies within the range estimated by Andrade \& Kaplan (1998). As the asset payout rate we follow Huang \& Huang (2003) and use 6 percent and consistent with Stohs \& Mauer (1996) we use an average debt maturity of 3.38 years $\left(\frac{T}{2}=3.38\right)$. See Huang \& Huang $(2003)$ and Ericsson et al. (2006) for a careful description of the Leland \& Toft (1996) model.

${ }^{43}$ Larsen (2006) reports correlations of similar magnitude.
} 
lower risk shifting. This effect mainly exists among firms that are close to financial distress. The mitigating effect on risk shifting due to strong debt governance is economically meaningful. For example, among firms with high default probabilities, strong debt governance is associated with a $25 \%$ reduction in industry-adjusted asset risk from the previous period.

We further investigate the role of debt governance in mitigating the effect of managerial risktaking incentives on risk shifting. Indeed, we find that, in the presence of strong debt governance, the positive effect on risk shifting of high managerial risk-taking incentives, measured by the sensitivity of $\mathrm{CEO}$ wealth to stock volatility, is largely eliminated. A caveat, however, is that this result appears to be sensitive to the definition of the debt governance proxies. Relating debt governance to the effect of Vega on the credit spreads of the bonds issued by the firm, we find that the impact of Vega on credit spreads is a function of the strength of debt governance. Bondholders generally view high Vega negatively when debt governance is weak. With strong debt governance, however, credit spreads are negatively associated with Vega.

Findings in this study raise at least two questions. First, by documenting that debt governance reduces risk shifting by mitigating the impact of managerial risk-taking incentives, we leave open the question of whether the resulting risk taking level is one step closer to the optimal level of firm risk. Furthermore, what is the value implication of the documented effect on the firm risk? Under the "nexus of contracts" view in Jensen \& Meckling (1976), these questions can't be approached without considering the interactions among different governance mechanisms designed for different claimholders. 


\section{A Appendix: The Merton model}

The Merton (1974) model is given as,

$$
E=V \exp \left(-\delta_{V} T\right) N\left(d_{1}^{E}\right)-D \exp (-r T) N\left(d_{2}^{E}\right)
$$

where the value of a firm's assets $V$ is lognormal and follows a geometric Brownian motion process $d V=\left(\mu_{V}-\delta_{V}\right) V d t+\sigma_{V} V d W_{V}$ with an instantaneous drift $\mu_{V} . \delta_{V}$ is the fraction of the firm's assets paid out to bondholders and equityholders, $\sigma_{V}$ is the instantaneous asset volatility, and $W_{V}$ is a standard Brownian motion. $D$ is the face value debt with maturity date $T$, and $r$ is the riskfree interest rate. $d_{1}^{E}=\left[\ln (V / D)+\left(r-\delta_{V}+\sigma_{V}^{2} / 2\right) T\right] / \sigma_{V} \sqrt{T}, d_{2}^{E}=d_{1}^{E}-\sigma_{V} \sqrt{T}$ and $N(\cdot)$ is the standard normal distribution function. 


\section{B Appendix: Description of Covenant Provisions}

\begin{tabular}{|c|c|c|}
\hline Covenant Name & Category & Description \\
\hline $\begin{array}{l}\text { CHANGE CONTROL } \\
\text { PUT PROVISIONS }\end{array}$ & Event & $\begin{array}{l}\text { Upon a change of control in the issuer, bondholders have the option of } \\
\text { selling the issue back to the issuer (poison put). Other conditions may limit } \\
\text { the bondholder's ability to exercise the put option. Poison puts are often } \\
\text { used when a company fears an unwanted takeover by ensuring that a } \\
\text { successful hostile takeover bid will trigger an event that substantially } \\
\text { reduces the value of the company. }\end{array}$ \\
\hline $\begin{array}{l}\text { RATING DECLINE } \\
\text { TRIGGER PUT }\end{array}$ & Event & $\begin{array}{l}\text { A decline in the credit rating of the issuer (or issue) triggers } \\
\text { a bondholder put provision. }\end{array}$ \\
\hline CROSS DEFAULT & Default & $\begin{array}{l}\text { A bondholder protective covenant that will activate an event of default in their } \\
\text { issue, if an event of default has occurred under any other debt of the company. }\end{array}$ \\
\hline $\begin{array}{l}\text { CROSS } \\
\text { ACCELERATION }\end{array}$ & Default & $\begin{array}{l}\text { A bondholder protective covenant that allows the holder to accelerate } \\
\text { their debt, if any other debt of the organization has been accelerated } \\
\text { due to an event of default. }\end{array}$ \\
\hline $\begin{array}{l}\text { DIVIDENDS } \\
\text { RELATED PAYMENTS }\end{array}$ & Dividend & $\begin{array}{l}\text { Flag indicating that payments made to shareholders or other entities may } \\
\text { be limit to a certain percentage of net income or some other ratio. }\end{array}$ \\
\hline $\begin{array}{l}\text { RESTRICTED } \\
\text { PAYMENTS }\end{array}$ & Dividend & Restricts issuer's freedom to make payments to shareholders and others. \\
\hline FUNDED DEBT & Financing & $\begin{array}{l}\text { Restricts issuer from issuing additional funded debt. Funded debt is } \\
\text { any debt with an initial maturity of one year or longer. }\end{array}$ \\
\hline INDEBTEDNESS & Financing & $\begin{array}{l}\text { Restricts user from incurring additional debt with limits on absolute } \\
\text { dollar amount of debt outstanding or percentage total capital. }\end{array}$ \\
\hline LIENS & Financing & $\begin{array}{l}\text { In the case of default, the bondholders have the legal right to sell } \\
\text { mortgaged property to satisfy their unpaid obligations. }\end{array}$ \\
\hline SALES LEASEBACK & Financing & $\begin{array}{l}\text { Restricts issuer to the type or amount of property used in a sale leaseback } \\
\text { transaction and may restrict its use of the proceeds of the sale. }\end{array}$ \\
\hline $\begin{array}{l}\text { SENIOR DEBT } \\
\text { ISSUANCE }\end{array}$ & Financing & Restricts issuer to the amount of senior debt it may issue in the future. \\
\hline $\begin{array}{l}\text { STOCK ISSUANCE } \\
\text { ISSUER }\end{array}$ & Financing & Restricts issuer from issuing additional common stock. \\
\hline $\begin{array}{l}\text { STOCK TRANSFER } \\
\text { SALE DISPOSAL }\end{array}$ & Financing & Restricts issuer from transferring, selling, or disposing of its common stock. \\
\hline $\begin{array}{l}\text { SUBORDINATED } \\
\text { DEBT ISSUANCE }\end{array}$ & Financing & Restricts issuance of junior or subordinated debt. \\
\hline $\begin{array}{l}\text { NET EARNINGS } \\
\text { TEST ISSUANCE }\end{array}$ & Financing & $\begin{array}{l}\text { To issue additional debt the issuer must have achieved or maintained } \\
\text { certain profitability levels. This test is a variations of the (more common) } \\
\text { fixed coverage tests. }\end{array}$ \\
\hline
\end{tabular}




\begin{tabular}{|c|c|c|}
\hline Covenant Name & Category & Description \\
\hline LEVERAGE TEST & Financing & Restricts total-indebtedness of the issuer. \\
\hline $\begin{array}{l}\text { NEGATIVE PLEDGE } \\
\text { COVENANT }\end{array}$ & Financing & $\begin{array}{l}\text { The issuer cannot issue secured debt unless it secures the current issue } \\
\text { on a pari passu basis. }\end{array}$ \\
\hline $\begin{array}{l}\text { BORROWING } \\
\text { RESTRICTED }\end{array}$ & Financing & Indicates subsidiaries are restricted from borrowing, except from parent. \\
\hline $\begin{array}{l}\text { DIVIDENDS } \\
\text { RELATED PAYMENTS }\end{array}$ & Financing & $\begin{array}{l}\text { Limits the subsidiaries' payment of dividends to a certain percentage } \\
\text { of net income or some other ratio. For captive finance subsidiaries, this } \\
\text { provision limits the amount of dividends which can be paid to the parent. } \\
\text { This provision protects the bondholder against a parent from draining } \\
\text { assets from its subsidiaries. }\end{array}$ \\
\hline STOCK ISSUANCE & Financing & $\begin{array}{l}\text { Restricts issuer from issuing additional common stock in restricted } \\
\text { subsidiaries. Restricted subsidiaries are those which are considered } \\
\text { to be consolidated for financial test purposes. }\end{array}$ \\
\hline $\begin{array}{l}\text { PREFERRED STOCK } \\
\text { ISSUANCE }\end{array}$ & Financing & Restricts subsidiaries' ability to issue preferred stock. \\
\hline $\begin{array}{l}\text { SUBSIDIARY } \\
\text { LEVERAGE TEST }\end{array}$ & Financing & Limits subsidiaries leverage. \\
\hline $\begin{array}{l}\text { CONSOLIDATION } \\
\text { MERGER }\end{array}$ & Investment & $\begin{array}{l}\text { Indicates that a consolidation or merger of the issuer with another } \\
\text { entity is restricted. }\end{array}$ \\
\hline INVESTMENTS & Investment & Restricts issuer's investment policy to prevent risky investments. \\
\hline $\begin{array}{l}\text { MAINTENANCE NET } \\
\text { WORTH }\end{array}$ & Investment & Issuer must maintain a minimum specified net worth. \\
\hline SALE ASSETS & Investment & $\begin{array}{l}\text { Restrictions on the ability of an issuer to sell assets or restrictions on } \\
\text { the issuer's use of the proceeds from the sale of assets. Such restrictions } \\
\text { may require the issuer to apply some or all of the sales proceeds to the } \\
\text { repurchase of debt through a tender offer or call. }\end{array}$ \\
\hline $\begin{array}{l}\text { TRANSACTION } \\
\text { AFFILIATES }\end{array}$ & Investment & Issuer is restricted in certain business dealings with its subsidiaries. \\
\hline $\begin{array}{l}\text { FIXED CHARGE } \\
\text { COVERAGE }\end{array}$ & Investment & $\begin{array}{l}\text { Issuer is required to have a ratio of earnings available for fixed charges, } \\
\text { of at least a minimum specified level. }\end{array}$ \\
\hline $\begin{array}{l}\text { DECLINING NET } \\
\text { WORTH }\end{array}$ & Investment & $\begin{array}{l}\text { If issuer's net worth (as defined) falls below minimum level, certain bond } \\
\text { provisions are triggered. }\end{array}$ \\
\hline $\begin{array}{l}\text { ASSET SALE } \\
\text { CLAUSE }\end{array}$ & Investment & $\begin{array}{l}\text { Covenant requiring the issuer to use net proceeds from the sale of } \\
\text { certain assets to redeem the bonds at par or at a premium. }\end{array}$ \\
\hline
\end{tabular}




\begin{tabular}{|c|c|c|}
\hline Covenant Name & Category & Description \\
\hline $\begin{array}{l}\text { INVESTMENTS } \\
\text { UNRESTRICTED }\end{array}$ & Investment & Restricts subsidiaries' investments. \\
\hline $\begin{array}{l}\text { SALE TRANSFER } \\
\text { ASSETS } \\
\text { UNRESTRICTED }\end{array}$ & Investment & $\begin{array}{l}\text { Issuer must use proceeds from sale of subsidiaries' assets (either certain } \\
\text { asset sales or all asset sales over some threshold) to reduce debt. }\end{array}$ \\
\hline $\begin{array}{l}\text { SUBSIDIARY } \\
\text { REDESIGNATION }\end{array}$ & Investment & $\begin{array}{l}\text { Indicates if restricted subsidiaries may be reclassified as unrestricted } \\
\text { subsidiaries. Restricted subsidiaries are those which are considered } \\
\text { to be consolidated for financial test purposes. }\end{array}$ \\
\hline $\begin{array}{l}\text { SALES } \\
\text { LEASEBACK }\end{array}$ & Investment & $\begin{array}{l}\text { Restricts subsidiaries from selling then leasing back assets that provide } \\
\text { security for the bondholder. This provision usually requires that assets } \\
\text { or cash equal to the property sold and leased back be applied to the } \\
\text { retirement of the debt in question or used to acquire another property to } \\
\text { increase the debtholders' security. }\end{array}$ \\
\hline LIENS & Investment & Restricts subsidiaries from acquiring liens on their property. \\
\hline $\begin{array}{l}\text { FIXED CHARGE } \\
\text { COVERAGE }\end{array}$ & Investment & $\begin{array}{l}\text { Subsidiaries are required to maintain a minimum ratio of net income } \\
\text { to fixed charges. }\end{array}$ \\
\hline $\begin{array}{l}\text { COVENANT } \\
\text { DEFEASANCE } \\
\text { WITHOUT TAX } \\
\text { CONSEQUENCE }\end{array}$ & Other & $\begin{array}{l}\text { Covenant defeasance only, is permitted. Issuer's legal counsel's } \\
\text { opinion states that bondholders will not recognize income for federal } \\
\text { tax purposes as a result of the defeasance. Covenant defeasance removes } \\
\text { the debt from the issuer's balance sheet and frees the issuer from the other } \\
\text { covenants, but the bondholder claims on revenues and other } \\
\text { security are not extinguished. }\end{array}$ \\
\hline $\begin{array}{l}\text { LEGAL } \\
\text { DEFEASANCE }\end{array}$ & Other & $\begin{array}{l}\text { Legal defeasance may occur. Legal defeasance removes the issue } \\
\text { from the issuer's balance sheet and frees the issuer from any indenture terms } \\
\text { (including security pledges). It occurs when the issuer places in an escrow } \\
\text { account an amount of money or U.S. government securities sufficient to match } \\
\text { the remaining interest and principle payments of the current issue. }\end{array}$ \\
\hline $\begin{array}{l}\text { DEFEASANCE } \\
\text { WITHOUT TAX } \\
\text { CONSEQUENCE }\end{array}$ & Other & $\begin{array}{l}\text { Legal defeasance may occur and issuer's legal counsel's opinion states } \\
\text { that bondholders will not recognize income for federal tax purposes as } \\
\text { a result of the defeasance. Legal defeasance removes the issue from the } \\
\text { issuer's balance sheet and frees the issuer from any indenture terms (including } \\
\text { security pledges). It occurs when the issuer places in an escrow account an } \\
\text { amount of money or U.S. government securities sufficient to match the } \\
\text { remaining principle and interest payments of the current issue. }\end{array}$ \\
\hline
\end{tabular}




\begin{tabular}{|l|l|l|}
\hline Covenant Name & Category & Description \\
\hline $\begin{array}{l}\text { AFTER ACQUIRED } \\
\text { PROPERTY CLAUSE }\end{array}$ & Other & $\begin{array}{l}\text { Property acquired after the sale of current debt issues will be included in the } \\
\text { current issuer's mortgage. Normally found in utility issuers with blanket } \\
\text { mortgages. }\end{array}$ \\
\hline $\begin{array}{l}\text { ECONOMIC } \\
\text { COVENANT }\end{array}$ & Other & $\begin{array}{l}\text { Gives the issuer the right to defease indenture covenants. If exercised, } \\
\text { this would free the issuer from the covenants set forth in the indenture } \\
\text { or prospectus, but leaves them liable for the remaining debt. This type of } \\
\text { defeasance may have tax consequences for the bond holders. }\end{array}$ \\
\hline $\begin{array}{l}\text { SUBSIDIARY } \\
\text { GUARANTEE }\end{array}$ & Other & $\begin{array}{l}\text { Subsidiary guarantees the payment of interest and/or repayment of principal } \\
\text { for the parent's debt issues. }\end{array}$ \\
\hline
\end{tabular}




\section{Appendix: Computation of Delta and Vega Measures}

We use the approximation method by Guay (1999) and Core \& Guay (2002) to compute Delta (the sensitivity of the option value with respect to a $1 \%$ change in stock price) and Vega (the sensitivity of the option value with respect to a 0.01 change in stock volatility).

The information on option-based compensation is obtained from Execucomp that provides data on new grants, unexercisable, and exercisable options. Execucomp provides sufficient information to compute Delta and Vega for new grants, whereas we need to rely on the Core \& Guay (2002) approximation method to compute the incentive measures for all outstanding unexercisable and exercisable options.

We follow Core \& Guay (2002) and estimate an average strike price and time to maturity for unexercisable and exercisable options. The average strike price is (year-end stock price realizable value/number of options), where the realizable value is the potential gain from exercising all outstanding options. The time to maturity of exercisable options is either equal to three years less the life of the current year's option grants or six years if the firm made no option grants in the current year. The time to maturity of unexercisable options is either equal to one year less the life of current year's option grants or nine years if the firm made no option grants the current year.

The total dollar values of Delta and Vega from the option portfolio inferred from the BlackScholes-Merton model are given as,

$$
\begin{aligned}
\text { Delta }_{t} & =\sum_{j=1}^{3} n_{t j} * 0.01 \exp \left(-\delta_{S} T_{j}\right) S_{t} N\left(Z_{1 j}^{S}\right), \\
\text { Vega }_{t} & =\sum_{j=1}^{3} n_{t j} * 0.01 \exp \left(-\delta_{S} T_{j}\right) S_{t} \sqrt{T_{j}} N^{\prime}\left(Z_{1 j}^{S}\right),
\end{aligned}
$$

where $j$ denotes option characteristics of (1) new grants, (2) unexercisable options and (3) exercisable options. $n_{t j}$ denotes the number of options for group $j, \delta_{S}$ is the expected annual dividend rate over the life of the option, $T_{j}$ is time to maturity for options in group $j$ (in years), $S_{t}$ is the current stock price, $K_{j}$ is the strike price of options in group $j, r$ is the continuous risk-free interest rate, $\sigma_{S}$ is the annualized stock return volatility, $Z_{1 j}^{S}=\left[\ln \left(S_{t} / K_{j}\right)+\left(r-\delta_{S}+\sigma_{S}^{2} / 2\right) T_{j}\right] / \sigma_{S} \sqrt{T_{j}}$, $N(\cdot)$ is the standard normal distribution function, and $N^{\prime}(\cdot)$ is the normal density function. 


\section{Appendix: Variable definitions}

\section{D.1 Key variables}

- IRAR (the industry-adjusted risk adjustment ratio) is equal to the difference between the risk adjustment ratio (RAR) and the median RAR of the firms in the same 2-digit SIC coded industry and in the same year, where RAR is the ratio between the current and the next year's asset volatility.

- Cov_J is the value-weighted covenant J-Index value.

- Cov_W is the value-weighted covenant W-Index value.

- Scale_J is a scaled covenant protection measure which equals the Cov_J value in a given firm year divided by the maximum value of Cov_J. The same applies for the covenant W-Index (Scale_W).

- Cov_J_quar ${ }_{i}$ is an indicator variable equal to one if the firm in a given year has a Cov_J value in the $i$ quartile, where $i=2,3$ and 4 . The same applies for the covenant W-Index $($ Cov_W_quar $i)$.

- Cov_J_h is an indicator variable equal to one if the firm in a given year has a Cov_J value above the median Cov_J. The same applies for the covenant W-Index (Cov_W_h).

- DP denotes the default probability inferred from the Merton (1974) model.

- DP_quar4 is an indicator variable equal to one if the firm in a given year is in the upper default probability quartile.

- DP*Scale_J is the cross product between DP and Scale_J. The same applies for the covenant W-Index $\left(\mathbf{D P}^{*}\right.$ Scale_W $)$.

- DP_quar4*Cov_J_h is an indicator variable equal to one if the firm in a given year is in the upper default quartile and has a Cov_J value above the median covenant index value. The same applies for the covenant W-Index $\left(\mathbf{D P} \_\right.$quar4*Cov_W_h$)$.

- Delta is the change in the dollar value of the executive's wealth for a one-percentage point change in stock price. A more detailed description is provided in Appendix C.

- Vega is the change in the dollar value of the executive's wealth for a one-percentage point change in the annualized standard deviation of description is provided in Appendix C.

- Vega_quar4 is an indicator variable equal to one if the executives in a given year have a Vega value greater than the upper risk incentive quartile. 


\section{D.2 Control variables}

We define our control variables with COMPUSTAT item numbers in parenthesis.

- Asset Risk denotes the annual asset volatility is inferred from the Merton (1974) model.

- Surplus Cash is the ratio of [operating activities(308) - depreciation and amortization(125) + research and development expense $(\max (0,46))]$ to $[$ total $\operatorname{assets}(6)]$.

- Tangibility is the ratio of [net, property, plant \& equipment(8)] to [total assets(6)].

- Market-to-book is the ratio of [total assets(6) - total common equity (60) + closing price(199) * common shares outstanding $(25)]$ to [total assets(6)].

- Book Leverage is the ratio of [long-term debt(9) + debt in current liabilities(34)] to [total $\operatorname{assets}(6)]$.

- Firm Size is the $\log [$ total assets(6)].

- Lagged Stock Return is the log of annualized gross return of a company's stock in the previous month.

- Stock Volatility is the annualized stock return volatility in the previous 180 days.

- Return on Asset is [Income Before Extraordinary Items (18)/Asset(6)]

- Interest Coverage is [Operating Income After Depreciation (178)/Interest Expense (15) $+1]$

- Coupon is the annualized interest rate of each bond issue.

- Time to Maturity is the remaining years to maturity of each bond issue.

- Issue Size is the outstanding face value of each bond issue.

- Callability is a dummy which is equal to 1 if the bond is callable.

\section{References}

Abarbanell, J. \& Bernard, V. (2000), 'Is the u.s. stock market myopic?', Journal of Accounting Research 38(2), 221-242.

Altman, E. I. (1968), 'Financial ratios, discriminant analysis and the prediction of corporate bankruptcy', Journal of Finance 23(4), 589-609. 
Amihud, Y. \& Lev, B. (1981), 'Risk reduction as a managerial motive for conglomerate mergers', The Bell Journal of Economics 12(2), 605-617.

Andrade, G. \& Kaplan, S. N. (1998), 'How costly is financial (not economic) distress? evidence from highly leveraged transactions that became distressed', Journal of Finance 53(5), 1443-1493.

Bagnani, E. S., Milonas, N. T., Saunders, A. \& Travlos, N. G. (1994), 'Managers, owners, and the pricing of risky debt: An empirical analysis', Journal of Finance 49(2), 453-477.

Barnea, A., Haugen, R. A. \& Senbet, L. W. (1980), 'A rationale for debt maturity structure and call provisions in the agency theoretic framework', Journal of Finance 35(5), 1223-1234.

Begley, J. \& Chamberlain, S. (2005), 'The use of debt covenants in public debt: The role of accounting quality and reputation', Working Paper, University of British Columbia pp. 1-31.

Begley, J. \& Feltham, G. A. (1999), 'An empirical examination of the relation between debt contracts and management incentives', Journal of Accounting and Economics 27, 229-259.

Berkovitch, E. \& Kim, E. H. (1990), 'Financial contracting and leverage induced over- and underinvestment incentives', Journal of Finance 45(3), 765-794.

Berlin, M. \& Mester, L. J. (1992), 'Debt covenants and renegotiation', Journal of Financial Intermediation 2, 95-133.

Bhanot, K. \& Mello, A. S. (2006), 'Should corporate debt include a rating trigger?', Journal of Financial Economics 79, 69-98.

Bharath, S. T. \& Shumway, T. (2004), 'Forecasting default with the KMV-merton model', Working Paper.

Bhojraj, S. \& Sengupta, P. (2003), 'Effect of corporate governance on bond ratings and yields: The role of institutional investors and outside directors', Journal of Business 76(3), 455-475.

Billet, M. T., King, T.-H. D. \& Mauer, D. C. (2006), 'Growth opportunities and the choice of levarage, debt maturity, and covenants', Journal of Finance, Forthcoming .

Black, F. \& Cox, J. C. (1976), 'Valuing corporate securities: Some effects of bond indenture provisions', The Journal of Finance 31(2), 351-367.

Black, F. \& Scholes, M. (1973), 'The pricing of options and corporate liabilities', The Journal of Political Economy 81(3), 637-654.

Bradley, M. \& Roberts, M. R. (2004), 'The structure and pricing of corporate debt covenants', Working Paper, The Fuqua School of Business, Duke University . 
Brisley, N. (2006), 'Executive stock options: Early exercise provisions and risk-taking incentives', Journal of Finance 61(5), 2487-2509.

Brown, K. C., Harlow, W. V. \& Starks, L. T. (1996), 'Of tournaments and temptations: An analysis of managerial incentives in the mutual fund industry', Journal of Finance 51, 85-110.

Carpenter, J. N. (2000), 'Does option compensation increase managerial risk appetite?', The Journal of Finance 55, 2311-2331.

Chava, S., Dierker, M., Livdan, D. \& Purnanandam, A. (2007), 'Do shareholder rights affect the cost of bank loans?', Working Paper, University of Houston .

Chava, S. \& Roberts, M. R. (2006), 'Is financial contracting costly? an empirical analysis of debt covenants and corporate investment', Working Paper, The Wharton School, University of Pennsylvania pp. 1-60.

Childs, P. D., Mauer, D. C. \& Ott, S. H. (2005), 'Interactions of corporate financing and investment decisions:the effects of agency conflicts', Journal of Financial Economics 76, 667-690.

Cohen, R. B., Hall, B. J. \& Viceira, L. M. (2000), 'Do executive stock options encourage risktaking?', Unpublished working paper, Harvard Business School .

Coles, J. L., Daniel, N. D. \& Naveen, L. (2006), 'Managerial incentives and risk-taking', Journal of Financial Economics 79(2), 431-468.

Core, J. \& Guay, W. (2002), 'Estimating the value of employee stock option portfolios and their sensitivities to price and volatility', Journal of Accounting Research 40(3), 613-630.

Crabbe, L. (1991), 'Event risk: An analysis of losses to bondholders and "super poison put" bond covenants', Journal of Finance 46(2), 689-706.

Cremers, K. J. M., Nair, V. B. \& Wei, C. (2007), 'Governance mechanisms and bond prices', Review of Financial Studies, Forthcoming .

Crosbie, P. \& Bohn, J. (2003), 'Modeling default risk', Moody's KMV pp. 1-31.

Crouhy, M., Galai, D. \& Mark, R. (2000), 'A comparative analysis of current credit risk models', Journal of Banking and Finance 24, 59-117.

Daniel, N. D., Martin, J. S. \& Naveen, L. (2004), 'The hidden cost of managerial incentives: Evidence from the bond and stock markets', Working Paper, Georgia State University .

DeFusco, R. A., Johnson, R. R. \& Zorn, T. S. (1990), 'The effect of executive stock option plans on stockholders and bondholders', The Journal of Finance 45(2), 617-627. 
Duan, J.-C., Gauthier, G. \& Simonato, J.-G. (2004), 'On the equivalence of the KMV and maximum likelihood methods for structural credit risk models', Working Paper .

Elton, E. J., Gruber, M. J., Agrawal, D. \& Mann, C. (2001), 'Explaining the rate of spread on corporate bonds', Journal of Finance 56(1), 247-277.

Ericsson, J., Reneby, J. \& Wang, H. (2006), 'Can structural models price default risk? evidence from bond and credit derivative markets', Working Paper, McGill University .

Esty, B. C. (1997a), 'Organizational form and risk taking in the savings and loan industry', Journal of Financial Economics 44(1), 25-55.

Fama, E. F. \& MacBeth, J. D. (1973), 'Risk, return, and equilibrium: Empirical tests', Journal of Political Economy 81(3), 607-636.

Fang, M. \& Zhong, R. (2004), 'Default risk, firm's characteristics, and risk shifting', Yale ICF Working Paper (04-21).

FitchRatings (2004), 'Evaluating corporate governance: The bondholders' perspective', Credit Policy - Special Report.

Galai, D. \& Masulis, R. W. (1976), 'The option pricing model and the risk factor of stock', Journal of Financial Economics 3, 53-81.

Gavish, B. \& Kalay, A. (1983), 'On the asset substitution problem', Journal of Financial and Quantitative Analysis 18(1), 21-30.

Gompers, P., Ishii, J. \& Metrick, A. (2003), 'Corporate governance and equity prices', Quarterly Journal of Economics 118(1), 107-155.

Goyal, V. K. (2005), 'Market discipline of bank risk: Evidence from subordinated debt contracts', Journal of Financial Intermediation 14, 318-350.

Guay, W. R. (1999), 'The sensitivity of CEO wealth to equity risk: An analysis of the magnitude and determinants', Journal of Financial Economics 53, 43-71.

Hall, B. J. \& Murphy, K. J. (2002), 'Stock options for undiversified executives', Journal of Accounting and Economics 33, 3-42.

Haugen, R. A. \& Senbet, L. W. (1981), 'Resolving the agency problems of external capital through options', The Journal of Finance 36(3), 629-647.

Heston, S. L. (1993), 'A closed-form solution for options with stochastic volatility with applications to bond and currency options', The Review of Financial Studies 6(2), 327-343. 
Hillegeist, S. A., Keating, E. K., Gram, D. P. \& Lundstedt, K. G. (2004), 'Assessing the probability of bankruptcy', Review of Accounting Studies 9, 5-34.

Hirshleifer, D. \& Suh, Y. (1992), 'Risk, managerial effort, and project choice', Journal of Financial Intermediation 2, 308-345.

Hjortsh $\varnothing$ j, T. (2006), 'Managerial risk-shifting incentives of option-based compensation: Firm risk, leverage, and moneyness', Working Paper, School of Economics and Management, University of Aarhus .

Holmström, B. (1979), 'Moral hazard and observability', The Bell Journal of Economics 10(1), 7491.

Huang, J.-Z. \& Huang, M. (2003), 'How much of the corporate-treasury yield spread is due to credit risk?', SSRN Working Paper .

Jensen, M. C. (1986), 'Agency costs of free cash flow, corporate finance, and takeovers', American Economic Review 76(2), 323-329.

Jensen, M. C. \& Meckling, W. H. (1976), 'Theory of the firm: Managerial behavior, agency costs and ownership structure', Journal of Financial Economics 3, 305-360.

Jin, L., Merton, R. C. \& Bodie, Z. (2006), 'Do a firm's equity returns reflect the risk of its pension plan?', Journal of Financial Economics 81(1), 1-26.

John, K. \& Kalay, A. (1982), 'Costly contracting and optimal payout constraints', Journal of Finance 37(2), 457-470.

John, K., Saunders, A. \& Senbet, L. W. (2000), 'A theory of bank regulation and management compensation', Review of Financial Studies 13(1), 95-125.

John, K. \& Senbet, L. W. (1998), 'Corporate governance and board effectiveness', Journal of Banking and Finance 22(4), 371-403.

John, T. A. \& John, K. (1993), 'Top-management compensation and capital structure', The Journal of Finance 48(3), 949-974.

Johnson, S. A. \& Tian, Y. S. (2004), 'Risk-averse executives, multiple common risks, and the efficiency and incentives of indexed executive stock options', Journal of Derivatives Accounting $\mathbf{1}(1), 11-28$.

Ju, N., Leland, H. \& Senbet, L. W. (2002), 'Options, option repricing and severance packages in managerial compensation: Their effects on corporate risk', Unpublished working paper, University of Maryland . 
Kahen, M. \& Tuckman, B. (1993), 'Do bondholders lose from junk bond covenant changes?', Journal of Business 66(4), 499-516.

Kahen, M. \& Yermack, D. (1998), 'Investment opportunities and the design of debt securities', Journal of Law, Economics and Organization 14(1), 136-151.

Klock, M. S., Mansi, S. A. \& Maxwell, W. F. (2005), 'Does corporate governance matter to bondholders?', Journal of Financial and Quantitative Analysis 40(4), 693-719.

Lambert, R. A. (1986), 'Executive effort and selection of risky projects', Rand Journal of Economics 17(1), 77-88.

Lambert, R. A., Larcker, D. F. \& Verrecchia, R. E. (1991), 'Portfolio considerations in valuing executive compensation', Journal of Accounting Research 29(1), 129-149.

Lando, D. (2004), Credit Risk Modeling: Theory and Applications, Princeton University Press.

Larsen, P. T. (2006), 'Default risk, debt maturity and levered equity's risk shifting incentives', Working Paper, University of Aarhus .

Leland, H. E. (1994), 'Corporate debt value, bond covenants, and optimal capital structure', The Journal of Finance 49(4), 1213-1252.

Leland, H. E. (1998), 'Agency costs, risk management, and capital structure', Journal of Finance 53(4), 1213-1243.

Leland, H. E. \& Toft, K. B. (1996), 'Optimal capital structure, endogenous bankruptcy, and the term structure of credit spreads', The Journal of Finance 51(3), 987-1019.

Lewellen, K. (2006), 'Financing decisions when managers are risk averse', Journal of Financial Economics 82, 551-589.

Longstaff, F. A. \& Schwartz, E. S. (1995), 'A simple approach to valuing risky fixed and floating rate debt', The Journal of Finance 50(3), 789-819.

Malitz, I. (1986), 'On financial contracting: The determinants of bond covenants', Financial Management 15(2), 18-25.

Mansi, S. A. \& Reeb, D. M. (2002), 'Corporate diversification: What gets discounted?', Journal of Finance 57(5), 2167-2183.

May, D. O. (1995), 'Do managerial motives influence firm risk reduction strategies', The Journal of Finance 50(4), 1291-1308. 
Merton, R. C. (1973), 'Theory of rational option pricing', The Bell Journal of Economics and Managerial Science 4(1), 141-183.

Merton, R. C. (1974), 'On the pricing of corporate debt: The risk structure of interest rates', The Journal of Finance 29(2), 449-470.

Moody's (2005), 'CEO compensation and credit risk', Moody's Investor Service - Special Comment

Myers, S. C. (1977), 'Determinants of corporate borrowing', Journal of Financial Economics 5, 147175.

Nash, R. C., Netter, J. M. \& Poulsen, A. B. (2003), 'Determinants of contractual relations between shareholders and bondholders: Investment opportunities and restrictive covenants', Journal of Corporate Finance 9, 201-232.

Nohel, T. \& Todd, S. (2004), 'Stock options and managerial incentives to invest', Journal of Derivatives Accounting 1(1), 29-46.

Ohlson, J. A. (1980), 'Financial ratios and the probabilistic prediction of bankruptcy', Journal of Accounting Research 18(1), 109-131.

Parrino, R., Poteshman, A. M. \& Weisbach, M. S. (2005), 'Measuring investment distortions when risk-averse managers decide whether to undertake risky projects', Financial Mangement pp. 2160 .

Parrino, R. \& Weisbach, M. S. (1999), 'Measuring investment distortions arising from stockholderbondholder conflicts', Journal of Financial Economics 53, 3-42.

Pontiff, J. (1996), 'Costly arbitrage: Evidence from closed-end funds', The Quaterly Journal of Economics 111(4), 1135-1151.

Purnanandam, A. (2005), 'Financial distress and corporate risk management: Theory and evidence', Working Paper .

Rajgopal, S. \& Shevlin, T. (2002), 'Empirical evidence on the relation between stock option compensation and risk taking', Journal of Accounting and Economics 33, 145-171.

Reisz, A. S. \& Perlich, C. (2004), 'A market-baed framework for bankruptcy prediction', Working Paper .

Ross, S. A. (2004), 'Compensation, incentives, and the duality of risk aversion and riskiness', The Journal of Finance 59(1), 207-225. 
Shleifer, A. \& Vishny, R. W. (1997), 'A survey of corporate governance', Journal of Finance $\mathbf{5 2}(2), 737-783$.

Skinner, D. J. (1989), 'Options markets and stock return volatility', Journal of Financial Economics 23, 61-78.

Smith, C. W. \& Stulz, R. M. (1985), 'The determinants of firms' hedging policies', Journal of Financial and Quantitative Analysis 20(4), 391-405.

Smith, C. W. \& Warner, J. B. (1979), 'On financial contracting an analysis of bond covenants', Journal of Financial Economics 7, 117-161.

Standard \& Poor's (2004), 'Standard and poor's corporate governance scores and evaluation criteria, methodology and definitions', Standard and Poor's Governance Services .

Stein, E. M. \& Stein, J. C. (1991), 'Stock price distributions with stochastic volatility: An analytic approach', The Review of Financial Studies 4(4), 727-752.

Stohs, M. H. \& Mauer, D. C. (1996), 'The determinants of corporate debt maturity structure', Journal of Business 69(3), 279-312.

Sundaram, R. K. \& Yermack, D. L. (2005), 'Pay me later: Inside debt and its role in managerial compensation', Working Paper No. 05-08, New York University, Law and Economics Research Paper Series .

Tirole, J. (2001), 'Corporate governance', Econometrica 69(1), 1-35.

Vassalou, M. \& Xing, Y. (2004), 'Default risk in equity returns', The Journal of Finance 59(2), 831868.

Warga, A. \& Welch, I. (1993), 'Bondholder losses in leveraged buyouts', Review of Financial Studies 6(4), 959-982.

Wei, C. (2006), 'Covenant protection, credit spread dynamics and managerial incentives', Working Paper, New York University . 
Figure 1: Time Series Means and Medians on Key Variables

This figure shows time-series means and medians in debt covenant measures (Cov_J and Cov_W) and the industry adjusted risk adjustment ratio (IRAR). In each panel the median is the solid line and the mean is the short dashed line. Variables are as described in Appendix D.
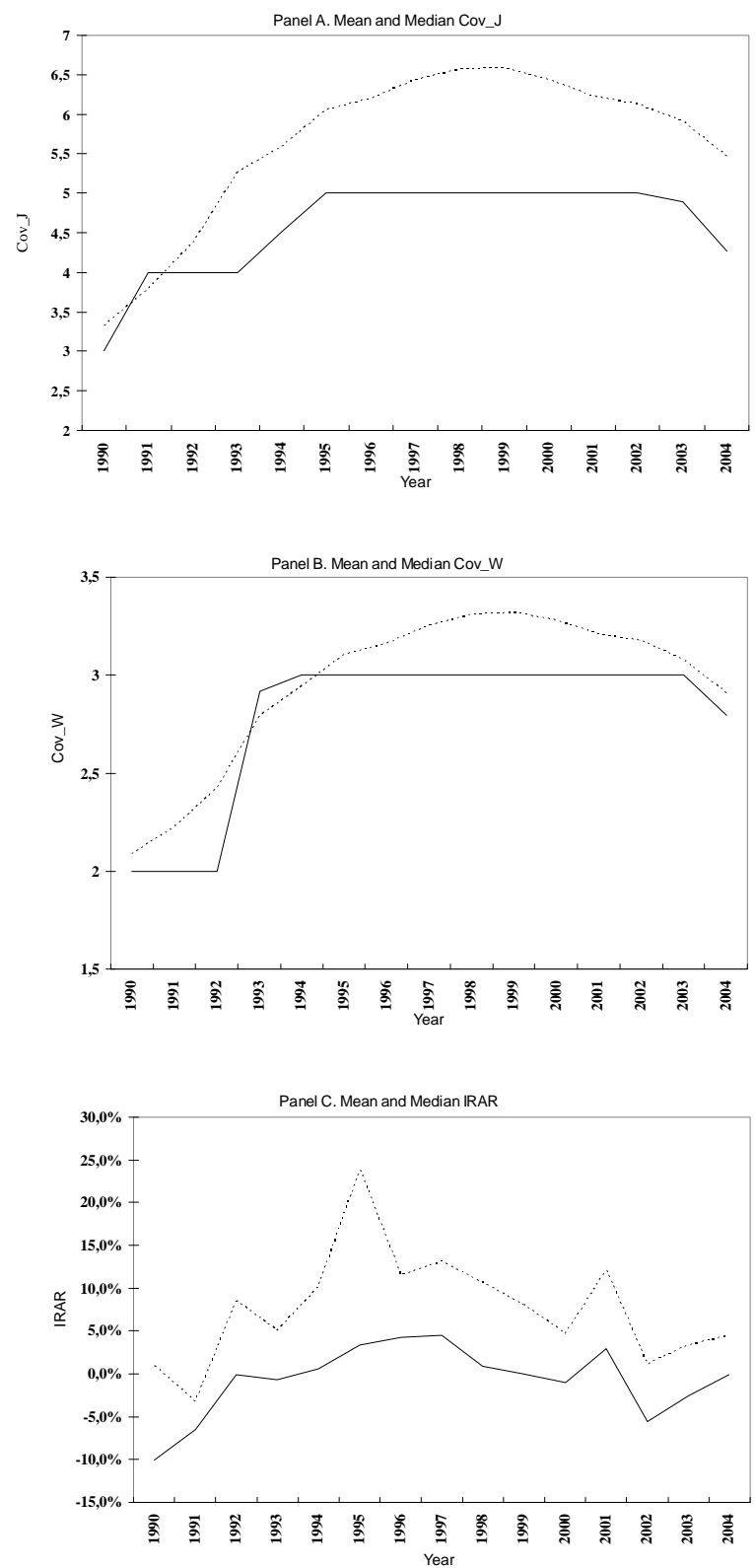


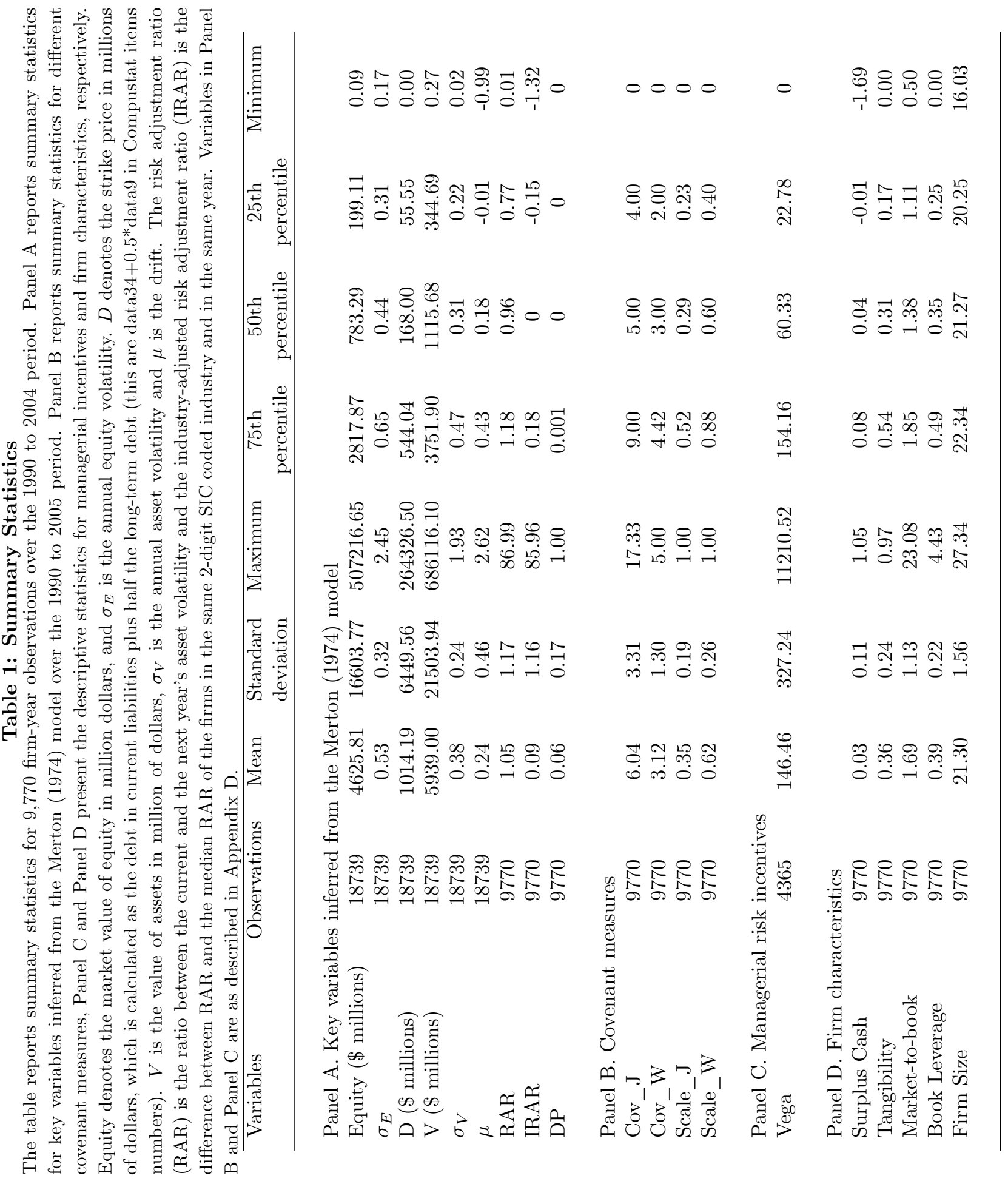


Table 2: Time Series Characteristics of Key Variables

The table reports the annual sample mean and median RARs (Panel A) and IRARs (Panel B), respectively. Panel C reports annual sample mean and median firm-level covenant J-Index values (Cov_J) and covenant W-Index Values (Cov_W), which is defined in Appendix D. Observations denote the number of firm-years. The risk adjustment ratio (RAR) is the ratio between the current and the next year's asset volatility and the industry-adjusted risk adjustment ratio (IRAR) is the difference between RAR and the median RAR of the firms in the same 2-digit SIC coded industry and in the same year.

\begin{tabular}{ccccccc} 
& & \multicolumn{2}{c}{ Panel A. RAR } & & \multicolumn{2}{c}{ Panel B. IRAR } \\
\cline { 3 - 4 } \cline { 6 - 7 } Year & Observations & Mean & Median & & Mean & Median \\
\hline 1990 & 59 & 1.01 & 0.91 & & 0.01 & -0.10 \\
1991 & 118 & 0.96 & 0.92 & & -0.03 & -0.06 \\
1992 & 261 & 1.07 & 0.98 & & 0.08 & 0.00 \\
1993 & 445 & 1.01 & 0.96 & & 0.05 & -0.01 \\
1994 & 579 & 1.07 & 0.98 & & 0.10 & 0.01 \\
1995 & 645 & 1.25 & 1.04 & & 0.24 & 0.03 \\
1996 & 710 & 1.11 & 1.05 & & 0.12 & 0.04 \\
1997 & 795 & 1.27 & 1.19 & & 0.13 & 0.05 \\
1998 & 908 & 1.04 & 0.95 & & 0.11 & 0.01 \\
1999 & 935 & 1.20 & 1.10 & & 0.08 & 0.00 \\
2000 & 895 & 0.88 & 0.81 & & 0.05 & -0.01 \\
2001 & 880 & 1.04 & 0.95 & & 0.12 & 0.03 \\
2002 & 866 & 0.79 & 0.72 & & 0.01 & -0.06 \\
2003 & 868 & 1.00 & 0.92 & & 0.03 & -0.03 \\
2004 & 806 & 1.00 & 0.96 & & 0.04 & 0.00 \\
All Years & 9770 & 1.05 & 0.96 & & 0.09 & 0.00 \\
& & & & & \\
\hline
\end{tabular}


Table 2: Time Series Characteristics of Key Variables (continued)

Panel C. Firm-level debt governance measure

\begin{tabular}{|c|c|c|c|c|c|}
\hline \multirow[b]{2}{*}{ Year } & \multirow[b]{2}{*}{ Observations } & \multicolumn{2}{|c|}{ Cov_J } & \multicolumn{2}{|c|}{ Cov_W } \\
\hline & & Mean & Median & Mean & Median \\
\hline 1990 & 59 & 3.32 & 3.00 & 2.09 & 2.00 \\
\hline 1991 & 118 & 3.79 & 4.00 & 2.22 & 2.00 \\
\hline 1992 & 261 & 4.38 & 4.00 & 2.42 & 2.00 \\
\hline 1993 & 445 & 5.26 & 4.00 & 2.79 & 2.92 \\
\hline 1994 & 579 & 5.60 & 4.51 & 2.94 & 3.00 \\
\hline 1995 & 645 & 6.06 & 5.00 & 3.10 & 3.00 \\
\hline 1996 & 710 & 6.21 & 5.00 & 3.16 & 3.00 \\
\hline 1997 & 795 & 6.44 & 5.00 & 3.25 & 3.00 \\
\hline 1998 & 908 & 6.57 & 5.00 & 3.31 & 3.00 \\
\hline 1999 & 935 & 6.59 & 5.00 & 3.32 & 3.00 \\
\hline 2000 & 895 & 6.44 & 5.00 & 3.28 & 3.00 \\
\hline 2001 & 880 & 6.23 & 5.00 & 3.21 & 3.00 \\
\hline 2002 & 866 & 6.13 & 5.00 & 3.18 & 3.00 \\
\hline 2003 & 868 & 5.90 & 4.90 & 3.08 & 3.00 \\
\hline 2004 & 806 & 5.47 & 4.27 & 2.91 & 2.79 \\
\hline All Years & 9770 & 6.04 & 5.00 & 3.12 & 3.00 \\
\hline
\end{tabular}




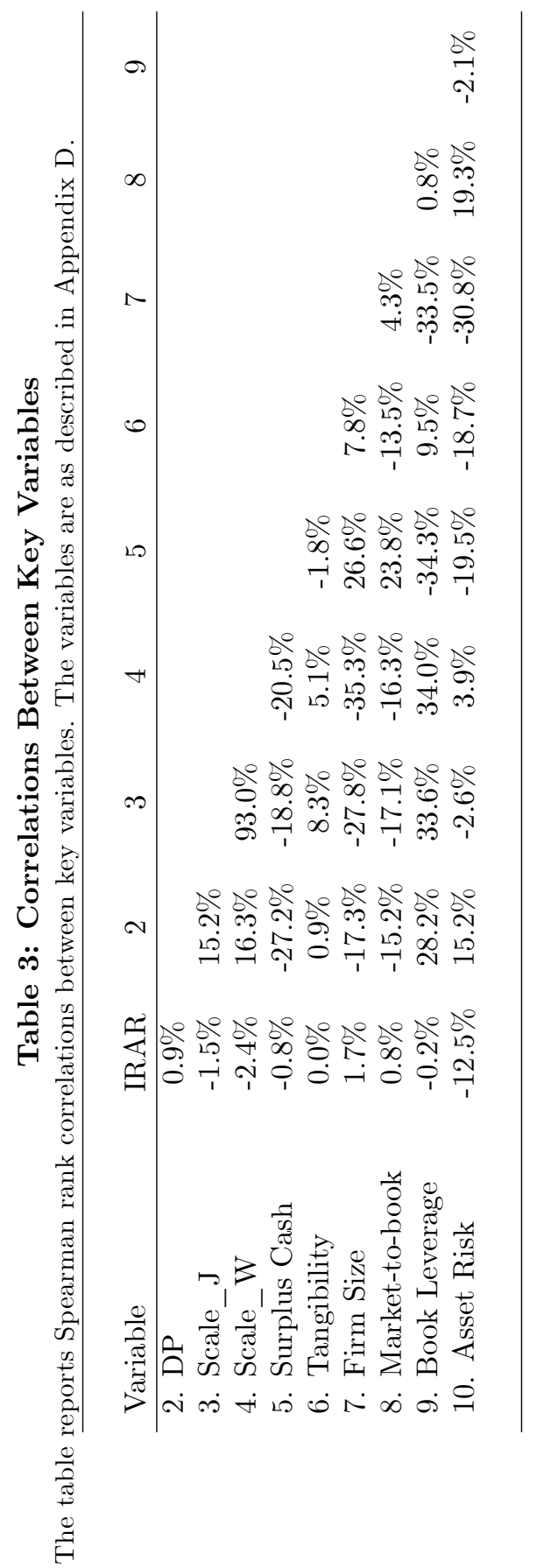


Table 4: Risk Taking and Debt Governance

The table reports Fama-MacBeth regression results with IRAR as the dependent variable. The variables are as described in Appendix D and the t-statistics are reported in parentheses below the parameter estimates. $* * *, * *$ and $*$ denote significance at the $1 \%, 5 \%$, and $10 \%$ levels, respectively.

\begin{tabular}{|c|c|c|c|c|}
\hline $\begin{array}{l}\text { Model } \\
\text { Independent variables }\end{array}$ & M1 & M2 & M3 & M4 \\
\hline Intercept & $\begin{array}{c}1.20^{* * *} \\
(4.74)\end{array}$ & $\begin{array}{c}1.30^{* * *} \\
(6.41)\end{array}$ & $\begin{array}{c}1.16^{* * *} \\
(4.21)\end{array}$ & $\begin{array}{c}1.20^{* * *} \\
(4.70)\end{array}$ \\
\hline Scale_J & $\begin{array}{c}-0.25^{* * *} \\
(-2.86)\end{array}$ & & & \\
\hline Scale_W & & $\begin{array}{c}-0.17^{* * *} \\
(-2.52)\end{array}$ & & \\
\hline Cov_J_quar4 & & & $\begin{array}{c}-0.08^{* * *} \\
(-3.78)\end{array}$ & \\
\hline Cov_J_quar3 & & & $\begin{array}{c}-0.08^{* * *} \\
(-2.86)\end{array}$ & \\
\hline Cov_J_quar2 & & & $\begin{array}{c}-0.04 \\
(-0.97)\end{array}$ & \\
\hline Cov_W_quar4 & & & & $\begin{array}{c}-0.05^{* * *} \\
(-3.00)\end{array}$ \\
\hline Cov_W_quar3 & & & & $\begin{array}{c}-0.05^{* * *} \\
(-2.54)\end{array}$ \\
\hline Cov_W_quar2 & & & & $\begin{array}{l}-0.04 \\
(-1.16)\end{array}$ \\
\hline Surplus Cash & $\begin{array}{c}-0.63^{* * *} \\
(-3.76)\end{array}$ & $\begin{array}{c}-0.62^{* * *} \\
(-3.77)\end{array}$ & $\begin{array}{c}-0.63^{* * *} \\
(-3.82)\end{array}$ & $\begin{array}{c}-0.63^{* * *} \\
(-3.73)\end{array}$ \\
\hline Tangibility & $\begin{array}{l}-0.07 \\
(-1.35)\end{array}$ & $\begin{array}{l}-0.08 \\
(-1.39)\end{array}$ & $\begin{array}{l}-0.08^{*} \\
(-1.66)\end{array}$ & $\begin{array}{l}-0.08 \\
(-1.49)\end{array}$ \\
\hline Market-to-book & $\begin{array}{c}0.03^{* * *} \\
(2.87)\end{array}$ & $\begin{array}{l}0.03^{* *} \\
(2.55)\end{array}$ & $\begin{array}{c}0.04^{* * *} \\
(2.99)\end{array}$ & $\begin{array}{c}0.03^{* * *} \\
(2.84)\end{array}$ \\
\hline Book Leverage & $\begin{array}{c}-0.16^{* *} \\
(-2.43)\end{array}$ & $\begin{array}{l}-0.15^{* *} \\
(-2.25)\end{array}$ & $\begin{array}{c}-0.17^{* * *} \\
(-2.78)\end{array}$ & $\begin{array}{c}-0.17^{* * *} \\
(-2.63)\end{array}$ \\
\hline Firm Size & $\begin{array}{c}-0.03^{* *} \\
(-2.14)\end{array}$ & $\begin{array}{c}-0.03^{* * *} \\
(-2.67)\end{array}$ & $\begin{array}{l}-0.03^{*} \\
(-1.88)\end{array}$ & $\begin{array}{l}-0.03^{* *} \\
(-2.17)\end{array}$ \\
\hline Asset Risk & $\begin{array}{c}-1.00^{* * *} \\
(-11.38)\end{array}$ & $\begin{array}{c}-0.99^{* * *} \\
(-11.24)\end{array}$ & $\begin{array}{c}-1.02^{* * *} \\
(-11.30)\end{array}$ & $\begin{array}{r}-1.00^{* * *} \\
(-11.52)\end{array}$ \\
\hline Observations & 9770 & 9770 & 9770 & 9770 \\
\hline Ave. Adj. $R^{2}$ & $7.6 \%$ & $7.4 \%$ & $7.6 \%$ & $7.1 \%$ \\
\hline
\end{tabular}


Table 5: Risk Taking, Default Risk and Debt Governance

The table reports Fama-MacBeth regression results with IRAR as the dependent variable. The variables are as described in Appendix D and the t-statistics are reported in parentheses below the parameter estimates. $* * *, * *$ and $*$ denote significance at the $1 \%, 5 \%$, and $10 \%$ levels, respectively.

\begin{tabular}{|c|c|c|}
\hline $\begin{array}{l}\text { Model } \\
\text { Independent variables }\end{array}$ & M1 & M2 \\
\hline Intercept & $\begin{array}{c}1.12^{* * *} \\
(3.46)\end{array}$ & $\begin{array}{c}1.14^{* * *} \\
(3.45)\end{array}$ \\
\hline DP_quar4 & $\begin{array}{c}0.20 \\
(1.53)\end{array}$ & $\begin{array}{c}0.20 \\
(1.54)\end{array}$ \\
\hline DP_quar4*Cov_J_h & $\begin{array}{c}-0.25^{* *} \\
(-2.09)\end{array}$ & \\
\hline $\mathrm{DP}_{-}$quar4${ }^{*} \mathrm{Cov} \_\mathrm{W}_{-} \mathrm{h}$ & & $\begin{array}{r}-0.25^{* *} \\
(-2.06)\end{array}$ \\
\hline Cov_J_h & $\begin{array}{c}0.00 \\
(-0.16)\end{array}$ & \\
\hline Cov_W_h & & $\begin{array}{c}0.02 \\
(0.57)\end{array}$ \\
\hline Surplus Cash & $\begin{array}{c}-0.61^{* * *} \\
(-3.98)\end{array}$ & $\begin{array}{c}-0.60^{* * *} \\
(-3.83)\end{array}$ \\
\hline Tangibility & $\begin{array}{l}-0.07 \\
(-1.47)\end{array}$ & $\begin{array}{l}-0.07 \\
(-1.49)\end{array}$ \\
\hline Market-to-book & $\begin{array}{c}0.05^{* * *} \\
(3.72)\end{array}$ & $\begin{array}{c}0.05^{* * *} \\
(3.89)\end{array}$ \\
\hline Book Leverage & $\begin{array}{c}-0.22^{* * *} \\
(-2.83)\end{array}$ & $\begin{array}{c}-0.24^{* * *} \\
(-2.68)\end{array}$ \\
\hline Firm Size & $\begin{array}{l}-0.03^{*} \\
(-1.77)\end{array}$ & $\begin{array}{l}-0.03^{*} \\
(-1.80)\end{array}$ \\
\hline Asset Risk & $\begin{array}{c}-1.07^{* * *} \\
(-9.27)\end{array}$ & $\begin{array}{c}-1.08^{* * *} \\
(-9.20)\end{array}$ \\
\hline Observations & 9770 & 9770 \\
\hline Ave. Adj. $R^{2}$ & $8.6 \%$ & $8.3 \%$ \\
\hline
\end{tabular}


Table 6: Risk Taking, Credit Rating and Debt Governance

The table reports Fama-MacBeth regression results with IRAR as the dependent variable. In Panel A, we consider investment grade firms. In Panel B, we consider speculative grade firms. The variables are as described in Appendix D and the t-statistics are reported in parentheses below the parameter estimates. $* * *, * *$ and $*$ denote significance at the $1 \%, 5 \%$, and $10 \%$ levels, respectively.

\begin{tabular}{|c|c|c|c|c|}
\hline \multirow[b]{2}{*}{$\begin{array}{l}\text { Model } \\
\text { Independent variables }\end{array}$} & \multicolumn{2}{|c|}{ Panel A. Investment Grade } & \multicolumn{2}{|c|}{ Panel B. Speculative Grade } \\
\hline & M1 & M2 & M3 & M4 \\
\hline Intercept & $\begin{array}{c}0.68 \\
(1.25)\end{array}$ & $\begin{array}{l}0.80^{*} \\
(1.92)\end{array}$ & $\begin{array}{l}0.96^{*} \\
(1.83)\end{array}$ & $\begin{array}{c}0.74 \\
(0.99)\end{array}$ \\
\hline Scale_J & $\begin{array}{l}-0.54 \\
(-1.01)\end{array}$ & & $\begin{array}{c}-0.27^{* *} \\
(-2.10)\end{array}$ & \\
\hline Scale_W & & $\begin{array}{l}-0.30 \\
(-0.91)\end{array}$ & & $\begin{array}{c}-0.20^{* *} \\
(-2.20)\end{array}$ \\
\hline Surplus Cash & $\begin{array}{l}-0.53^{*} \\
(-1.75)\end{array}$ & $\begin{array}{l}-0.53^{*} \\
(-1.75)\end{array}$ & $\begin{array}{c}-0.61^{* *} \\
(-2.42)\end{array}$ & $\begin{array}{c}-0.66^{* *} \\
(-2.45)\end{array}$ \\
\hline Tangibility & $\begin{array}{c}-0.17 \\
(-1.09)\end{array}$ & $\begin{array}{l}-0.16 \\
(-1.08)\end{array}$ & $\begin{array}{c}-0.01 \\
(-0.25)\end{array}$ & $\begin{array}{l}-0.05 \\
(-0.69)\end{array}$ \\
\hline Market-to-book & $\begin{array}{c}-0.01 \\
(-0.21)\end{array}$ & $\begin{array}{c}-0.01 \\
(-0.29)\end{array}$ & $\begin{array}{c}0.10^{* * *} \\
(3.28)\end{array}$ & $\begin{array}{c}0.11^{* * *} \\
(2.83)\end{array}$ \\
\hline Book Leverage & $\begin{array}{l}-0.55^{* *} \\
(-2.32)\end{array}$ & $\begin{array}{l}-0.57^{* *} \\
(-2.21)\end{array}$ & $\begin{array}{l}-0.19^{* *} \\
(-2.16)\end{array}$ & $\begin{array}{c}-0.17^{* *} \\
(-2.03)\end{array}$ \\
\hline Firm Size & $\begin{array}{c}0.01 \\
(0.29)\end{array}$ & $\begin{array}{c}0.01 \\
(0.20)\end{array}$ & $\begin{array}{l}-0.03 \\
(-1.12)\end{array}$ & $\begin{array}{c}-0.01 \\
(-0.45)\end{array}$ \\
\hline Asset Risk & $\begin{array}{c}-1.65^{* * *} \\
(-5.73)\end{array}$ & $\begin{array}{c}-1.64^{* * *} \\
(-5.74)\end{array}$ & $\begin{array}{c}-0.91^{* * *} \\
(-4.98)\end{array}$ & $\begin{array}{c}-0.80 * * * \\
(-2.96)\end{array}$ \\
\hline $\begin{array}{l}\text { Observations } \\
\text { Ave. Adj. } R^{2}\end{array}$ & $\begin{array}{l}3809 \\
8.2 \%\end{array}$ & $\begin{array}{l}3809 \\
7.9 \%\end{array}$ & $\begin{array}{c}4074 \\
10.1 \%\end{array}$ & $\begin{array}{c}4074 \\
10.1 \%\end{array}$ \\
\hline
\end{tabular}


Table 7: Risk Taking, Managerial Incentives and Debt Governance The table reports Fama-MacBeth regression results with IRAR as the dependent variable. The variables are as described in Appendix D and the t-statistics are reported in parentheses below the parameter estimates. $* * *, * *$ and $*$ denote significance at the $1 \%, 5 \%$, and $10 \%$ levels, respectively.

\begin{tabular}{|c|c|c|c|}
\hline $\begin{array}{l}\text { Model } \\
\text { Independent variables }\end{array}$ & M1 & M2 & M3 \\
\hline Intercept & $\begin{array}{c}1.22^{* * *} \\
(6.68)\end{array}$ & $\begin{array}{c}1.25^{* * *} \\
(6.35)\end{array}$ & $\begin{array}{c}1.19^{* * *} \\
(5.89)\end{array}$ \\
\hline Vega_quar4 & $\begin{array}{c}0.04^{* *} \\
(2.20)\end{array}$ & $\begin{array}{c}0.07^{* *} \\
(2.30)\end{array}$ & $\begin{array}{c}0.06^{* *} \\
(2.20)\end{array}$ \\
\hline Vega_quar4*Cov_J_h & & $\begin{array}{c}-0.06^{* *} \\
(-2.45)\end{array}$ & \\
\hline Vega_quar4*Cov_W_h & & & $\begin{array}{l}-0.04 \\
(-0.88)\end{array}$ \\
\hline $\mathrm{Cov}_{-} \mathrm{J}_{-} \mathrm{h}$ & & $\begin{array}{l}-0.01 \\
(-0.36)\end{array}$ & \\
\hline Cov_W_h & & & $\begin{array}{l}0.04^{*} \\
(1.70)\end{array}$ \\
\hline Surplus Cash & $\begin{array}{l}-0.10 \\
(-1.28)\end{array}$ & $\begin{array}{l}-0.11^{*} \\
(-1.71)\end{array}$ & $\begin{array}{l}-0.11^{*} \\
(-1.72)\end{array}$ \\
\hline Tangibility & $\begin{array}{l}-0.01 \\
(-0.49)\end{array}$ & $\begin{array}{l}-0.01 \\
(-0.45)\end{array}$ & $\begin{array}{l}-0.01 \\
(-0.48)\end{array}$ \\
\hline Market-to-book & $\begin{array}{c}0.02^{* *} \\
(2.03)\end{array}$ & $\begin{array}{l}0.02^{*} \\
(1.66)\end{array}$ & $\begin{array}{c}0.02^{* *} \\
(2.23)\end{array}$ \\
\hline Book Leverage & $\begin{array}{c}-0.22^{* * *} \\
(-7.11)\end{array}$ & $\begin{array}{c}-0.21^{* * *} \\
(-6.83)\end{array}$ & $\begin{array}{c}-0.23^{* * *} \\
(-6.82)\end{array}$ \\
\hline Firm Size & $\begin{array}{c}-0.04^{* * *} \\
(-4.79)\end{array}$ & $\begin{array}{c}-0.04^{* * *} \\
(-4.66)\end{array}$ & $\begin{array}{c}-0.04^{* * *} \\
(-4.21)\end{array}$ \\
\hline Asset Risk & $\begin{array}{c}-0.86^{* * *} \\
(-8.25)\end{array}$ & $\begin{array}{c}-0.86^{* * *} \\
(-8.31)\end{array}$ & $\begin{array}{c}-0.85 * * * \\
(-8.14)\end{array}$ \\
\hline $\begin{array}{l}\text { Observations } \\
\text { Ave Adi } R^{2}\end{array}$ & $\begin{array}{c}4365 \\
11.0 \%\end{array}$ & $\begin{array}{c}4365 \\
111 \%\end{array}$ & $\begin{array}{l}4365 \\
115 \%\end{array}$ \\
\hline Ave. Auj. $\Omega$ & $11.0 / 0$ & $11.1 / 0$ & $11.5 \%$ \\
\hline
\end{tabular}


Table 8: Credit Spreads, Managerial Incentives and Debt Governance

Panel A reports summary statistics for 30,320 firm-month observations over the 1993 to 1997 period. The table reports variables used in the credit spread analysis in Section 4.3.2. Controls for firm characteristics include size, Market-to-Book, lagged stock return, stock volatility, ROA, leverage and interest coverage. Controls for Issue characteristics include coupon, time to maturity, issue size and callability. Lastly, investment is a dummy which is equal to 1 if the bond is rated investment-grade.

Panel A. Summary Statistics

\begin{tabular}{|c|c|c|c|c|c|c|}
\hline Variables & Observations & Mean & Median & $\begin{array}{l}\text { Standard } \\
\text { deviation }\end{array}$ & Minimum & Maximum \\
\hline Credit Spread & 30320 & 1.19 & 0.91 & 0.85 & 0.10 & 6.77 \\
\hline Delta & 30320 & 0.44 & 0.19 & 0.77 & 0.002 & 8.52 \\
\hline Vega & 30320 & 0.08 & 0.05 & 0.09 & 0.00 & 0.78 \\
\hline Cov J & 30320 & 4.61 & 4.23 & 1.90 & 0 & 14.00 \\
\hline Cov_W & 30320 & 2.37 & 2.13 & 0.94 & 0 & 5.00 \\
\hline Firm Size & 30320 & 8.75 & 8.79 & 1.18 & 4.29 & 12.11 \\
\hline $\log ($ Market-to-book) & 30320 & 0.82 & 0.79 & 0.54 & -1.27 & 4.65 \\
\hline log(Lagged Stock Return) & 30320 & 0.01 & 0.01 & 0.07 & -0.61 & 0.42 \\
\hline $\log$ (Stock Volatility) & 30320 & 0.21 & 0.20 & 0.06 & 0.09 & 0.59 \\
\hline ROA & 30320 & 0.04 & 0.04 & 0.04 & -0.22 & 0.22 \\
\hline Book Leverage & 30320 & 0.33 & 0.33 & 0.11 & 0 & 0.88 \\
\hline Interest Coverage & 30320 & 5.39 & 4.35 & 15.66 & 0 & 943.94 \\
\hline Coupon & 30320 & 8.18 & 8.13 & 1.40 & 0 & 15.00 \\
\hline Time to Maturity & 30320 & 13.76 & 9.00 & 10.92 & 0.33 & 100.00 \\
\hline $\log$ (Issue Size) & 30320 & -1.72 & -1.74 & 0.50 & -3.40 & 0.66 \\
\hline Call & 30320 & 0.25 & 0.00 & 0.43 & 0.00 & 1.00 \\
\hline Investment & 30320 & 0.90 & 1.00 & 0.30 & 0.00 & 1.00 \\
\hline
\end{tabular}


Table 8: Credit Spreads, Managerial Incentives and Debt Governance (continued) Panel B reports Fama-MacBeth regressions that regresses corporate bond spreads on proxies for managerial incentives Delta and Vega (see Appendix D for a description), debt governance indices, the interaction of the two terms, a constant, plus a set of controls (omitted). In particular, we control firm characteristics including Firm Size, Market-to-Book, Lagged Stock Return, Stock Volatility, ROA, Leverage, Interest Coverage, and issue characteristics including Coupon, Time to Maturity, Issue Size and Callability. Lastly, we control for credit ratings using rating dummies for the finest rating classification. The t-statistics are reported in parentheses below the parameter estimates. $* * *, * *$ and $*$ denote significance at the $1 \%, 5 \%$, and $10 \%$ levels, respectively.

Panel B. Regression analysis

\begin{tabular}{lccc} 
Model & M1 & M2 & M3 \\
Independent variables & & & \\
\hline Intercept & $0.26^{* * *}$ & $0.26^{* * *}$ & $0.23^{* * *}$ \\
& $(4.74)$ & $(3.4)$ & $(2.93)$ \\
Delta & $0.01^{* *}$ & $0.01^{* *}$ & $0.01^{* *}$ \\
& $(2.04)$ & $(2.27)$ & $(2.02)$ \\
Vega & $0.26^{* * *}$ & $0.97^{* * *}$ & $0.70^{* * *}$ \\
& $(4.15)$ & $(7.01)$ & $(5.63)$ \\
Vega*Cov_J & & $-0.19^{* * *}$ & \\
& & $(-5.69)$ & \\
Vega*Cov_W & & & $-0.22^{* * *}$ \\
& & 0.004 & $(-3.95)$ \\
Cov_J & & $(0.88)$ & \\
& & & $0.01^{*}$ \\
Cov_W & & & $(1.7)$ \\
& & Omitted & \\
Firm Characteristics & & Omitted & \\
Issue Characteristics & & Omitted & \\
Credit Rating & & & \\
& 30320 & 30320 & 30320 \\
Observations & $84.7 \%$ & $84.9 \%$ & $84.8 \%$ \\
Ave. Adj. $R^{2}$ & & & \\
\hline
\end{tabular}

